University of Rhode Island

DigitalCommons@URI

Open Access Dissertations

1982

\title{
TRICYCLIC ANTIDEPRESSANTS AND SERUM IONIZED CALCIUM
}

Girolamo A. Ortolano

University of Rhode Island

Follow this and additional works at: https://digitalcommons.uri.edu/oa_diss

\section{Recommended Citation}

Ortolano, Girolamo A., "TRICYCLIC ANTIDEPRESSANTS AND SERUM IONIZED CALCIUM" (1982). Open Access Dissertations. Paper 160.

https://digitalcommons.uri.edu/oa_diss/160

This Dissertation is brought to you for free and open access by DigitalCommons@URI. It has been accepted for inclusion in Open Access Dissertations by an authorized administrator of DigitalCommons@URI. For more information, please contact digitalcommons-group@uri.edu. 
TFICYCLIC ANTIIEFFIESSANTS ANI SEFUM IONIZEI CALCIUM

BY

GIROLAMO A. OFTOLANO

A IISSEFTATION SUEMITTEI IN FAFTIAL FULFILLMENT OF THE FERUIFEMENTS FOF THE LIEGREE OF IIOCTOF: OF F'HILOSOFHY

IN

FHAFIMACOLOGY ANII TOXICOLOGY

UNIUEFSITY DF FHOIE ISLANII

1982 


\section{DOCTOF OF FHILOSOFHY IISSERTATION}

DF

GIROLAMO A. ORTOLANO

Afroroved:

Iissertation Committee Major Professor

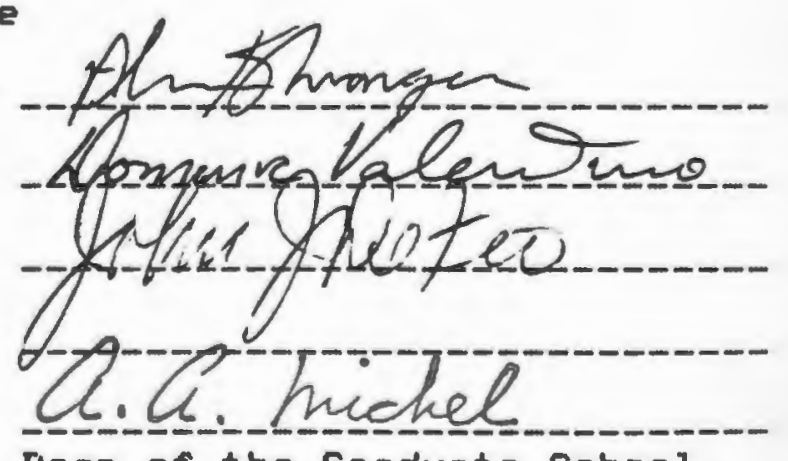
Dean of the Graduate School

UNIVEFSITY OF RHOIE ISLAND

1982 


\section{AESTFACT}

Serum iorized calcium has long been viewed as the physiolosically active form of calcium, yet the faucity of studies concerned with this resforise measure is affarent arid may be related to the hish cost of modern fotentiometric iristrumeritation. Feducing the cost factor was afproached by iritesrating arı inexpensive static-tyfe calcium iori-sfecific electrode into a fabricated flastic electrode chamber. Characteriaztion of the electrode system was ferformed by elucidating the oftimum farameters for electrode use in serum samples. Coriformance to the exterided Nicolsky-Eisenmarı equation was. used as a criterion for acceptable electrode system ferformance. Neslisable effects of froteins or the performarice of the electrode was established by comfarirs calcium biridis kirietics arid FH deferidence data obtairied with the system with values obtairied from the literature. The electrode systen was showr to correlate well when compared with the 0rior 5s-20 serum ionized calcium instrumerit with over $97 \%$ of the variarice accounted for by resressior. The admiristration of calcium chloride or the divalerit cation chelator, ethylere diamire tetracetic acid, to rats resulted iri predictable resfonses in serum iorized calcium.

The serum ionized calcium electrode system was emfloyed in tests of hypotheses concerniris serum ionized calcium and 
aritiderressant activity of the tricyclic aritiderressant, frotriftyline and the thyroid hormorie, tri-iodothyrorine. Fiats treated with protriftyline (10mg/kg) for 1,6 or 18 days and tested 2, 6, 12 arid 24 hours after the last dose failed to show sisnificart changes in serum ionized calcium. Similarly, arimals treated with tri-iodothyroririe at varyirs doses for 1,5 or 10 dass and tested 1,4 or 24 hours after the last dose also failed to show changes in this resfonse measure. Coricomitarit thyraid hormorie at varyiris doses and protriftuline (5mg/kg) did not result in changes in serum ionized calcium or in aris resforise measures studied which are either krown or are susfected to be reflective of chariges in calcium homeostasis. The results failed to suffort a calcium hyfothesis of aritidefressant activity.

The results are at variarice with those of clirical studies amons defressives reforted in the literature. Iiscussion offers suffort for viewiris the rat as a foor arimal model for studying alterations in calcium nomeostasis. 


\section{ACKNOWLEIIGEMENTS}

I would like to chronolosically ack.rowledse so mariy people for the numerous ways my 1 ife and this work has heen affected by their very existence. I thank all of sou for what sou have siven me. Mom, dad, brother Len, Feter J. Ferrara, Arnie Heitner, Bob and Ilelores Dlander, Gary Carlson, Al Swonser, John Defeo, Ray Scienza, Earbara Strefpore, Crais Smith, John and Lynr, Muro, Ed Kiaiser, Rorı Stuart, Ken Wunschel, Jr, Rupert P. Hammond and last but not least my childern, Brett, Keith, Sabrina and Tiffany-Ann. 


\section{DEIICATION}

For my wife, Kathryn 


\section{PREFACE}

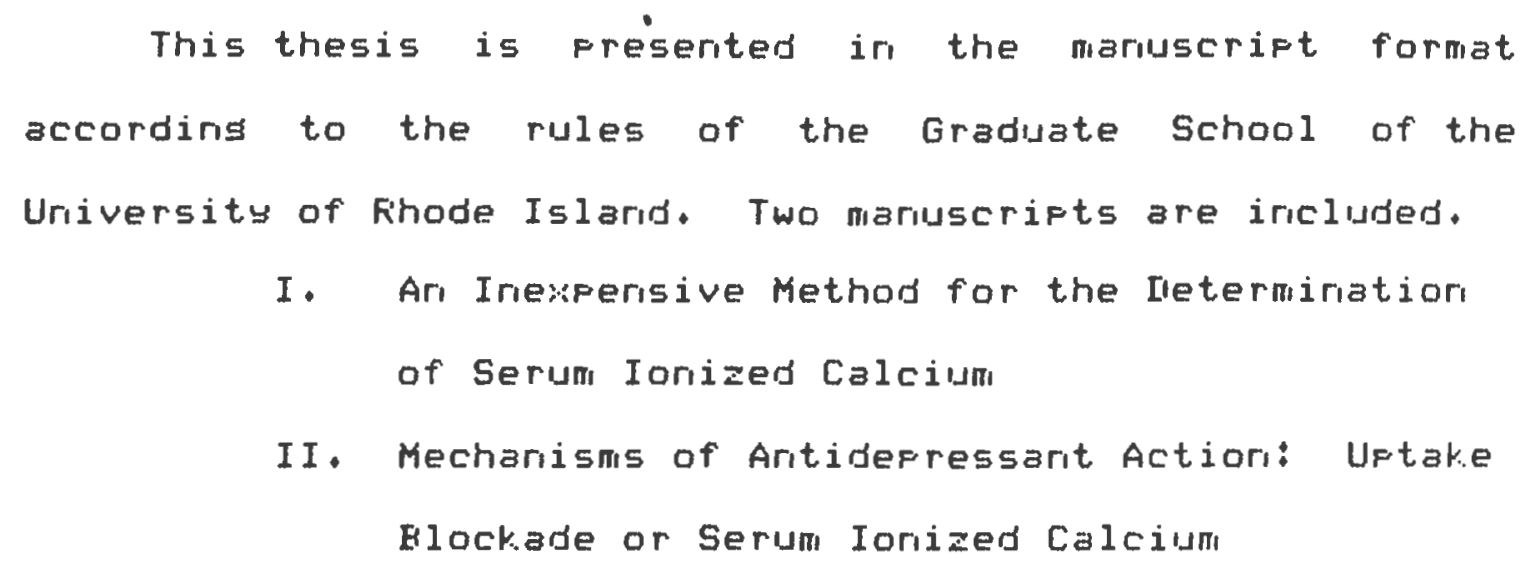


TAELE OF CONTENTS

LIST OF TAELES

viii

LIST OF FIGUFES

xi

AN INEXFENSIUE METHOI FOF THE IIETEFIMINATION OF

SEFUM IONIZEII CALCIUM

INTROIUCTION

2

MATEFIALS ANII METHOLS 3

$\begin{array}{lr}\text { RESULTS } & 11\end{array}$

IISCUSSION 18

$\begin{array}{ll}\text { SUMMAFYY } & 24\end{array}$

$\begin{array}{ll}\text { FIEFEFIENCES } & 26\end{array}$

FIGUFE TITLES ANI LEGENIS 39

MECHANISMS OF ANTIIEFFESSANT ACTION: UFTAKE

ELOCKAIE OF SEFUM IONIZEII CALCIUM

INTROIUCTION

MATERIIALS ANI METHOIS 56

$\begin{array}{ll}\text { FESULTS } & 61\end{array}$

IIISCUSSION 65

$\begin{array}{ll}\text { SUMMAFY } & 69\end{array}$

$\begin{array}{ll}\text { REFEFENCES } & 70\end{array}$

FIGUFE TITLES ANI LEGENIS 85

$\begin{array}{ll}\text { BIELIOGF'AF'HY } & 88\end{array}$ 


\section{LIST OF TABLES}

TAELE

F'AGE

AN INEXFENSIUE METHOI FOF THE IIETERMINATION OF

SEFUM IONIZEII CALCIUM

1. Critical Ilimensions and Ilescriftiors of

Flastic (Flexiglas(F')) Serum Sampling

Chamber

2. Comfarison of Various Corventions Used for the Iletermination of Single Ior Activity Coefficierits at $25^{\circ} \mathrm{C}$

3. Selectivity Ratios lletermined for Ions of Finssiologic Interest

4. Errors Associated with Calculated Values of Selectivity Fiatios

5. Liriear Fiegression Farameters for Standards at Varyirı Ioric Strengths Confaring Molar Coricentratior, Molar Activity and Molar Activity + Selectivity

6. Effects of Samele Frocessing on $=H$

7. Electrode Ferformarice Characteristics

8. The Effects of Subcutarieous Adniristratior of $\mathrm{CaCl}_{2}$ or EITA Ufor Total anid Iorized

Serum Calcium in Fiats 
9. Estimates of the Masnitude of Error Associated with Either Activity (a)

Effect Alone or Combined Activity Flus Selectivity Effects (atk)

MECHANISMS OF ANTIIEFRESSANT ACTION: UFTAKE HLOCKALE OF SERUM IONIZEII CALCIUM

1. Effect of Protriftyline (10ms/ks) Ufon Serum Ionized and Total Calcium

2. Effect of Tri-iodothyronine ( $T_{3}$ ) Administration on Serum Iorized and Total Calcium

3. The Effect of Concomitant Tri-iodothyrorine ( $T_{3}$ ) and Frotriftyline ( $5 \mathrm{~ms} / \mathrm{kg}$ ) Administration for 14 Dass Ufon Resfonse Measures Suspected to be Reflective of Calcium Homeostasis

4. The Effect of a Hish lose (20ms/kg) of Frotriftyline Chronically Administered (14 days) on Hody Weisht, Blood Constituents and Bone 
5A. The Effects of Subchronic (6 dass)

Frotriftyline (20ms/kg) Administration

Compared with Weisht Adjusted Controls on

Gross Indices of Metabolism

5F. The Effects of Subchronic (6 days)

Frotriftyline (20ms/ks) Administration

Comfared with Weisht Adjusted Controls ori

Urinary Indices of Calcium Metabolism

6. The Effect of a Hish Ilose (20ms/kg) of

Frotriftyline Subchronically Administered

(6 days) on Blood Constituents and Bore

7. The Effect of Therafeutically Relevant Iloses

of Frotriftyline $(0.5 \mathrm{~ms} / \mathrm{kg})$ and Imiframine

(5. Oms/ks) Administered Subchrorically

( 6 days) on Blood Constituents and Bane

84 


\section{LIST OF FIGURES}

F IGURE

PAGE

AN INEXFENSIVE METHOI FOR THE DETERMINATION OF

\section{SERUM IONIZEII CALCIUM}

1. Pictorial refresentation of the calcium ion-specific electrode chamber

2. Pictorial refresentatior of the bottom Plate of the electrode chamber

3. Photograph of the experimerital affaratus assembled for the determination of serum iorized calcium

4. Resfonse times of the electrode system incorforated into the electrode chamber

5. The effect of sample processirig temperature on serum iorized calcium

6. Calcium bindins to bovine serum albumin

7. Correlation between ionized calcium measured on the Orion 55-20 with that usiris the static type electrode

8. Effect of the duration of serum sample storase at $-20^{\circ} \mathrm{C}$ 
MECHANISMS OF ANTIDEFRESSANT ACTION: UPTAKE BLOCKALE OR SERUM IONIZED CALCIUM

1. The effect of ether administration on norefinephrine uptake into rat hyfothalmic synaftosomes

2. The effects of acute, subchronic arid chronic protriftyline administration ufor the uftake of norefinefhrine into rat hyfothalmic synaftosomes 
AN INEXF'ENSIUE METHOI FOR THE IIETERMINATION OF SERUM IONIZEI CALCIUM 


\section{INTRODUCTION}

Serum ionized calcium has long been viewed as the Phssiologically active form of calcium (20) but the laborious techniaues reauired for its determination have limited both clinical and experimental studies. In 1967, Foss (21) introduced the calcium ion-specific electrode (ISE) and a short time thereafter Orior, Research, Inc. made available a flow-throush calcium ISE desigried to measure ionized calcium in biolosical fluids araerobically. This moderately friced electrode is no lonser available and was reflaced by a much more expensive microfrocessor-controlled apparatus. Althoush other sophisticated iristrumerits are commercially available, it apfears that the faucity of literature concerning serum ionized calcium may be a direct result of the hish cost of iristrumeritation.

Reducing the cost factor was afproached by intesratiris an inexpensive static-type calcium ISE into an easily fabricated plastic electrode chamber to permit temperature-controlled, anaerobic sameling $(0,6 \mathrm{ml})$ with the aid of commonly available laboratory equifment including a serisitive $\mathrm{FH} / \mathrm{mV}$ meter and a circulatins water bath. Since the static-type ISE is not recommended for use with serum samples, this refort includes a characterization and application for such use. Also included are the construction details of the electrode chamber. 
MATEFIALS AND METHOIS

AeEaratus The foteritiometric components of the experimerital apfaratus, obtained from Orion Research, Inc. (Cambridge, Mass.), include an electrode body (model 93-00) attached to a calcium ISE sensing module (model 93-20) and a single junction refererice electrode (model 93-01) utilizing 4M KCl saturated with silver as the internal filling solution. The electrode potential was measured with an Orion disital $\mathrm{FH} / \mathrm{mV}$ meter (model $701 \mathrm{~A}$ ) in the relative mV mode. Sample temperature was controlled by circulatins water throush the plastic samplins chamber usins a constant temperature circulating fumf (HETO, Ilenmark; model 7402).

Serum FH was measured using a blood gas arialyzer (IL model 413).

Samelins Cbamber = Construction Details The folastic chamber was constructed of filexiglas(R) with critical dimerisions denoted in the pictorial refresentations (figures 1 and 2 ). A photosraph of the assembled affaratus is shown in fisure 3.

The flastic was cut to the required sizes indicated in table 1. Sides of the upper and lower assembly were fitted with 1/8. male hose adapters (Cole-palmer; Chicaso, I1.). Holes for the electrode bodies were drilled usins a spade 
bit (5/8") while the tor and bottom flates of the uffer assembly were held together to insure froper hole aligrimerit.

The bottom flate of the uffer assembly forms a major Fart of the sample comfartmerit. Sample eritry arid exit forts were made by drilling 1/16" chanriels obliquely from the ceriter of the frorit and back edses to riear the hottom of the electrode hody holes. A $1 / 16$ " troush was created by filiris the underside of the bottom flate between the electrode body holes. Threaded ends of female Instac(fi) Luer-Boss adafters (Lee Co.; Westbrook, Ct,) were grourid off, arid the resultarit flat surface sanded lightly. These adafters were comforierits of the samfle eritry arid exit forts. They were fitter over the chanrels, secures irito fosition with a arof of methylerie chloride arid further reiriforced with a bead of efory cemerit.

The electrode chamber was assembled arb held in Fosition with elastic barids. Methylerie chloride was afflied to all contacting surfaces with the ais of a glass syringe arid stainless steel needle. Ufori removal of the elastic barids, successive afFlicatiors of flastic shaviriss dissolved in methylerie chloride $(5 \%$ and then $15 \% \mathrm{w} / v)$ were made to provide leak-froof seals.

The electrodes were inserted irito the holes arid secured

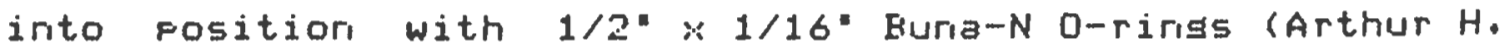


Thomas Co.: Fhila., Fa.). A sheet of teflori served as the remainiris part of the sample compartmerit. The distarice between the active surface of the electrodes arid the teflon sheet, aloris with the fosition of the 0-rings, determined the sample volume reauired for analysis. Gerierally, $0.6 \mathrm{ml}$ was reauired to completely fill the sample comfartmerit. The teflori was backed with cork sheetiris arid the lower assembly, cork, teflor sheet and uffer assembly were all held tosether with steel rods arid turribuckles (figure 3 ).

Use of the Samelias Chamber The assembled electrode chamber was orierited at 45 desrees with resfect to the samfle entry fort and a vertical flarie. This orientation frevented air from becoming traffed withir the sample comfartmerit. The sample was iritroduced irito the sample compartmerit with a syririge. The exit fort was capped with a Leur-Lock erid cas wher, the sample besari to emerge from the fort. The chamber was flushed 3 times with $3 \mathrm{ml}$ of isotoric salire between the iritroduction of samples arid standards.

Eeagents All chemicals were of reaserit srade (Fisher Scientific, Fa.) and solutioris were frefared with distilled - deionized water. Staridards were fresared from stock solutioris (M) of $\mathrm{NaCl}(4.0), \mathrm{KCl}(0.5), \mathrm{MsCl}_{2}(0.55)$, $\mathrm{CaCO}_{3}(0.1)$ dissolved in $\mathrm{HCl}(0.24), \mathrm{CaCl}_{2}(0.1), \mathrm{HCl}(1.0)$ and $\mathrm{NaOH}(1.0)$. Tris-(hydronsmethyl)-amirometharie (TFis, 1.0) and disodium ethyleriediamire tetracetic acid (EITA, 
$0.05)$ was purchased from Sigma Chemical Co. (St. Louis, Mo.).

Calculations A) Ioric strenstin- In the prefaration of standards at the ioric strergths giver, the coritribution of components excert $\mathrm{NaCl}$ towards ionic strensth ffollowins adjustment of the solution to $\mathrm{FH} 7.4$ with $\mathrm{NaOH}$ ) was calculated using the classical formula

$$
u=1 / 2 \sum \mathrm{CiZi}^{2}
$$

where:

$$
\begin{aligned}
& u=\text { ionic strength } \\
& C_{i}=\text { molar concentration of the ior, } i \\
& Z i=\text { the charge associated with ion, } i .
\end{aligned}
$$

Ari affrofriate amourit of $\mathrm{NaCl}$ was therı added to briris the solution to the desired ioric strensth. All standards coritained $5.0 \mathrm{mM} \mathrm{KCl}$ and $0.55 \mathrm{mM} M g C l_{2}$ aloris with varyirs amounts of $\mathrm{CaCl}_{2}$ arid $\mathrm{NaCl}$.

E) Individual Ior Activities- A variety of convertiors are available for estimatirı the activity coefficients of individual ioris at various ionic strensths. The data of Kielland was used by afflyirig folyromial regression aralysis on the logarition of the ioric strerigth as the iridefenderit variable versus the activity coefficiert. Secorid desree polsnomials fit the data well (F⿺.001) with makimum residuals of less than 5 percert. A comparison of the values obtained by various converitions aloris with those 
estimated by the restession analysis (FF-Ki) are fresented in table 2 aloris $w i \div h$ the regressiori parameters.

In this refort, molar concertrations will be refresented by brackets and activity by fareritheses.

C) Serum Iorized Calcium- These values were obtained by use of the equatior, [Catt] = antilos (siritercegt - mu readiris)/ slofe). The mu readings of two calcium staridards $(0.5$ and 5.0 mim) were taken in duflicate both before and after a series of samples were riur. The slofe was calculated by takins the difference in mu readings of averase values abtairied for low calcium and hish calcium staridards. The averase mV reading of the 1.0 min calcium standards bracketirig the sample was used in the equation to calculate the intercept for that sample. Early studies conducted with this system resulted in the observation that steady baselirie orifts occured over the rarige of conceritratioris of standards employed. Ir additior, a Faroxysmal shift in the mu readiris for a sample or staridard wäs observed. Errors associated with both types of shifts . are atteruated by this calculation frocedure.

Selectivity Eatios The equimolar conceritration $(0.1 \mathrm{M})$, sefarate solution method as described by sririvasan arid Rechnita (25) was used to determine selectivity ratios while the electrodes were removed from the samile chamber. 
Selectivity ratios are siver by:

$$
K_{c a-i}=\left(\operatorname{antilog}\left(\frac{E c a-E i}{s}\right)\right)\left(\frac{\left(C a^{++}\right)}{(i)^{2 / 2 i}}\right)
$$

where:

$k c^{-i}=$ selectivity ratio of the calcium ion sfecific electrode for the iriterferins ion, i.

$\mathrm{E} c a=$ observed foteritial of $30.1 \mathrm{M} \mathrm{CaCl} 2$ solution

$E i$ = observed potential of a $0.1 M$ solutior of the interferins ion, i.

$S=2.3 \mathrm{KT} / 2 \mathrm{~F}=$ Nerristian slofe with theoretical values of 29.58 at $25^{\circ} \mathrm{C}$ arid 30.77 at $37^{\circ} \mathrm{C}$.

$($ Catt) = activity of calcium in moles/L.

(i) = activity of the interfering ion in moles/L.

Calcium Albuminate bicetics Rovire serum albumin (ESA, Sisma Co.) at a concentration of $69 / 81$ was frefared in 50 mim acetate huffer (FH 4.4), dialyzed at $4^{\circ} \mathrm{C}$ for 24 hours with two forty-fold volume changes and subsequently dialyzed in a similar maniner in $50 \mathrm{mM}$ TFIS/HCl buffer (FH 7.4). lialysis at the isoelectric foirt of albumir served to reduce iritially elevated foteritials observed followiris the frefaration of proteins in TRIS buffer directly. The elevated fotentials were due primarily to low levels of calcium liberated from the ESA; 3 firiding corfirmed aualitatively by atomic absorption sfectroscopy. Followirs dialysis the resultarit conceritration of BSA was $4 \mathrm{~g} / d 1$, arid to $10 \mathrm{ml}$ of this solution, 5, 10, and $201 \mathrm{l}$ aliauots of 
$\mathrm{CaCl}_{2}$ (200mi) were added incrementally arid ionized calcium determined. TFIS was selected as an affrofriate buffer since the data of Moharı and Hates (14) showed calcium does not bind to TFIS over the rarise 0.01 to $0.1 \mathrm{M}$.

Statistical Aualysis The method of least saures was used to calculate regression farameters of second arid first desree folyriomials. Tests of sisrificarice between restession coefficierits were ferformed usiris the t-statistic as described by Steel arid Torrie (26). Where affropriate, the indeferident samfle or refeated measures t-statistic was sFflied.

Serum Sameles Humari blood samples were collected usiris 10 or $15 \mathrm{ml}$ "Vacutairiers" (red tof" no additive" Eectori-Ilickson; Futherford, N.J.) via the median cubital veir. The blood was allowed to clot at room temrerature for 20 mirutes, ceritrifused at $1000 \times s \times 10^{\prime}$ arid serum removed anaerobically usiris a disfosable syririse arid reedle. The serum ( $1 \mathrm{ml}$ ) was trarisferred to a 2.0 ml Vacutairier with the aid of a syringe and either stored on ice unitil ready for assay or frozer at $-20^{\circ} \mathrm{C}$.

Fat blood was collected usiris a disfosable 3 ml syrinse following light ether ariesthetization by puncturing the inferior vena cava. The blood was trarisferred anaerobically irito a $3 \mathrm{ml}$ Vacutainer arid frocessed as described for human 
serism.

Iest of Acaerabic Conditions Individual serum samfles were collected anaerobically in $1 \mathrm{ml}$ tuberculin syringes and fut on ice. Frior to measuring ionized calcium, fH measuremerits were made arid the remairing samble was frocessed throush the sample chamber and the gH was asain measured ufor its removal.

Static Iyee Electrode Versus the Drion SS=20 Sera of 10 riormal volunteers (ases 22 to 42 for males and 21 to 32 for females) were run in triflicate on the orion ss-20 accordins to the manufacturer's iristructiors arid also or the afraratius described in this regort. The remainiris serum was fooled anaerobically and six 1 ml samples withorawn and flaced into 2 ml Vacutainers for each of the followiris treatmerit groufs. A small volume (up to $20 \mathrm{Ll}$ ) of $\mathrm{CaCl}_{2}$ or ElITA was added to each Vacistairier.

Aeelication Male Cofs/CI rats (Charles fiver Co. Wilmington, Mass,) weighirı $350 \pm 50$ grams were grouf housed and fed food arid water ad libitum. Ten arid thirty minutes Frior to sacrifice, rats were injected subcutarieously ( $1 \mathrm{ml} / \mathrm{kg})$ with saline, $\mathrm{CaCl}_{2}$ or ElITA. Total serum calcium was measured using the o-cresofhthaleir complexorie reaction (Sisma Co.). 
F'AGE 11

RESULTS

Electrade Eeseanse Iime The resultant effects of iricorporatiris the electrodes into the chamber on electrode response time were evaluated using standards and samfles at both 25 arid $37^{\circ} \mathrm{C}$. The results illustrated in fisure 4 were reforted as deviations (in mV) from the 5 minute reabirs sirice the readirigs were showri to be stable from 5 to 30 mirutes. Shorter resforise times were obtained with measurements determiried at $25^{\circ} \mathrm{C}$. Althoush the data corverse or arı eauilibrium value at 5 mirutes, it should be made clear that the mU readings for samples arid staridards were different at the two temferatures studied.

Eased uforl the data showr irı fisure 4 , some auarititative differences associated with ionized calcium measured at the two temperatures would be expected. While mV measuremerits made at $37^{\circ} \mathrm{C}$ followiris a delay of 4 mirutes deviate from the equilibrium value by affroximately 0.11 arid $0.17 \mathrm{ml}$ for samples and standards, resfectively, they do not significantly differ from each other (F.0.05). Since the staridard deviatiors associated with measuremert at this time Foirit are small, the 4 mirute readins would be expected to give results virtually ideritical to the equilibrium value. The $25^{\circ} \mathrm{C}$ measuremerits made at 1 minute however, while they averase close to the eauilibrium value, are themselves sisnificantly different from each other $(F<0.05)$ with the 
staridards reading aforoximately 0.25 mV hisher than the samiles. To correct for this effect, the difference in mu $(0.25)$ is either added to the observed foteritial for the samile, or subtracted from the averase observed fotential for the standards bracketing the samfle. This value is aferoximately 0.02 mim calcium.

Fisure 5 illustrates the effect of temferature. The difference between the value obtained at $25^{\circ} \mathrm{C}$ corrected for equilibrium effects and those at $37^{\circ} \mathrm{C}$ is 0.04 mim Ca, or affrominately $4 \%$, a value consistent with those previously ohserved in the literature $(2,10)$.

Activitye Selectivity and bolar Concentrations Ior sfecific electrodes of the tspe emflosed here have heen shown to respond in accordance with the exterided Nicolskb-Eiserıma equation (7).

$$
E=E^{0}+S \log \left(\left(C a^{++}\right)+K c a-i(i)^{2 / Z_{i}}\right)
$$

where:

$$
E \text { = observed foteritial }
$$

$E^{0}=$ sum of foteritials orisiriatiris from the reference electrode, the filling solution of the iorm-sfecific electrode and the liauid junction foteritial.

Femaining terms as freviously defined. Conformarice to this equation was used as a criterior for assessirig the ferformance characteristics of the electrode 
system.

Table 3 deficts the results of selectivity ratios evaluated for ioris of frimarily fhysiolosic interest for each of two lot rumbers of calcium serısiris modules. The selectivity ratios obtained exferimeritally, wher comfared with calculated values freserited in table 4, determine which ioris sigrificarity coritribute to the observed foteritial through a selectivity effect.

Table 5 shows the resression farameters for calcium staridaras $(0.5$ to 1.7 iricremented by 0.3 mm) frefared at the ioric strengths indicated. Fesression farameters reveal ideritical slopes orly wher the activity arid selectivity effects are accourited for ir the arialysis, as fredicted by the Nicalsky-Eisermarı equatiorı.

Calcium=albuwiuate binetics The results of this experimerit deficted in figure $6 A$ indicate affareritly two saturable calcium biridins comporients associated with ESA. The data, arialyzed as described by Moore (16) arid illustrated in figure 6B, reflects the two saturable sites, each of which may be fitted accurately usiris lirear regression arialysis. Feplication of the experimerit resulted in essertially ideritical findings concerning the rumber of saturable comporients. The average results of three indefendent experimerits save calculated dissociatiorı corıstarits (Fli) for 
the hish and low corceritration ranses (subscrifted resfectively $H+L$ ) and rumber of binding sites ( $n$ ) of (mean $\pm 5 .\left[\Pi_{0}\right) F K_{H}=1.9 \pm .4, F K_{L}=2.9 \pm .1, r_{H}=12.7 \pm 2.2$ and $\Pi_{L}=$ 1.91.4. Mare imfortarity, after the electrodes had been exposed to solutions containiris froteins, the charise in the ohserved foteritial of the anueous standards from the hesiririris to the erid of the rur was corisisterit with withiri-das variation characteristically observed when the electrodes had heen used orly with fure acueous staridards, susgestiris that the electrodes can withstarid the freserice of Froteiris.

E甘 Effects A) Froteiri-Free Solutior- Iorized calcium was determiried at various levels of fH usiris 1.0 mim calcium frefared in $50 \mathrm{mM}$ TFIS at $\mathrm{FH} 6.7,7.4$ and 7.9 with $\mathrm{NaCl}$ adjusted to a resultarit ioric strerigth of 0.16 moles/L. The relatiorishif between iorized calcium and $\mathrm{PH}$ was fournd to be $\Delta\left[c_{a}+m_{1}=-0.087 \Delta \mathrm{FH}\right.$ a value virtually identical to the relatiorishif offered by Grima arid Erand (9). These data sugsest small hut sisrificarit errors are associated with FH charises over the fhysiological rarise.

E) Froteir solutiors- Studies similar to those reforted in the calcium-albumirate kirietics section were performed at $\mathrm{PH} 5.5$ where it was observed that 0.43 mim $\mathrm{Ca}$ was hourid to albumiri at 2.5 mm total calcium. Comfarins the value obtained at $\mathrm{FH} 7.4$ of $1.3 \mathrm{mM}$ hourid, described ir the 
freceding section, results in the fH defendent relationshif $\Delta[\mathrm{Ca}++] m \mathrm{~m}=-0.46 \quad \Delta \mathrm{FH}$ and adjusting for the froteiri concentration of $4 \quad s / d 1$ in this study comfared with 4.73 g/dl used by Moore, the correlation coefficient becomes -0.39 which is reasoriably close to the value of -0.42 reforted by moore (16). The rarige of values varies from -0.49 to $-0.35(6,18,24)$. It may be coricluded that the electrode system is resporisive to the change in free calcium associated with varyins fH ir froteir solutions.

C) Test of Ariaerobic Coriditions- The results (table 6 ) suggest that a sigrificarit iricrease in FH may result, but the masritude of the charige, i.e. $\left(\Delta\left[C_{a}+t\right]=-0.39 \times \Delta F H=\right.$ $-0.39 \because(.047)=-.018)$ is less tharl the error associated with the frecision of the measurement.

Electrode Eerformace Iluriris a 23 day feriod both serum samples and staridards were measured and the day to day and withir day variatioris of the standards were calculated with the results freserited in table 7. The data illustrates several imfortarit corisiderations. Electrode stability is fairly sood as reflected by a maximum coefficierit of variation of $1.5 \%$ associated with the $0.5 \mathrm{mM}$ staridard. Within day variation is aforeciable and warrants the calculation frotocol described in the methods section, whereby each sample is bracketed by the standards. The slofe does rot change affreciably from the besiririris to the 
end of the ruri, justifyins the use of the averase mu slofe determiried for the day in the calculatior of iorized calcium. The relative mu readirss for a given serisirs module mas differ sigrificaritly from any other module as Freviously shown in table 3. In addition, the data used for the frefaration of tables 5 and 7 utilized two different serısins modules. The averase mu readirıg for staridards siven in tahle 7 may be comfared with calculated mV values for the same calibration staridards obtained usiris the resression farameters of table $5, u=.16,[\mathrm{Cat}+], 25^{\circ} \mathrm{C}$. These values are $30.51,38.67$ and $57.63 \mathrm{ml}$ for $0.5,1.0$ and $5.0 \mathrm{~mm}$ calcium resfectively.

Static=Iyee Electrode versus tbe Driod SS=20 The mearis of triflicate serum sample determinations run or the 55-20 arid the static-tyfe electrode system are comfared in fisure 7. The correlation was corisidered to be excellent with over $97 \%$ of the variation accourited for by resression.

Samele Storage Humari serum samples frozen at $-20^{\circ} \mathrm{C}$ for varying periods of time were assayed to determine the effects of storase. Figure 8 illustrates a sigrificarit increase in calcium followirs storage, a result at variance with most reforted studies. This result sugsests that the effect of storase coriditiors deserves more thoroush characterization. Urider the giver, conditions, unless measuremerits are made immediately, the duration of freezing 
should he ideritical from ore sample to the riext arid should rot exceed two weer.s.

AeElication Eesults The effects ufor the observed serum total arid iorized calcium, as a result of the admiristration of $\mathrm{CaCl}_{2}$ or EIITA, are fresented in table 8 . fiats admiristered EITA showed a frofound decrease in hoth total arı iorized serum calcium whereas a sigrificarit increase in serum ioriaed calcium was observed for $\mathrm{CaCl}_{2}$ treated amirals desfite a small but irisigrificant increase in their total serum calcium. The results corfirm the iri-vitro effects of $\mathrm{CaCl}_{2}$ and EIITA arid suffort the view that the system described here carı easily resolve $10 \%$ chanses irı serum iorized calcium. 


\title{
IISCUSSION
}

\begin{abstract}
Several criteria must be met before calcium iori-sfecific electrodes mas be used to determirie serum ionized calcium. These criteria are associated with either the fhusical conditions under which measuremerits are made, the ferformarice of the electrode or the comfosition of the samile. Since the static-type electrodes have not been recommended for the determination of iorized calcium in serum, this refort focuses or the various criteria arid demoristrates how each have been satisfied in terms of the experimerital results.
\end{abstract}

Coricerring the fhssical coriditions surroundiris the measurement itself, the determination should be made ariaerobically or a sample of fixed volume at corstarit temperature. Any instrument designed to measure serum iorized calcium should be capable of retairing the orisirial $\mathrm{FH}$ of the sample followiris the measuremerit, since alterations in FH can substantially alter the measurement. The ISE sampliris chamber frovides for guasi-ariaerobic sample Frocessing, as shown by the $\mathrm{FH}$ data frovided.

Arrold et al. (2) demoristrated the deferidence of the measurement ufor samfle volume, which is fixed in the appearatus described here at $0.6 \mathrm{ml}$. This value is not corisiderably different from the volume of samile reauired 
for use of the SS-20.

The ideal coriditions for determiniris serum ionized calcium are those which most closely reflect fhysiolosic coriditions. A variety of temperatures have been used includiris $20^{\circ} \mathrm{C}(2), 25^{\circ} \mathrm{C}(12), 26^{\circ} \mathrm{C}(19), 27^{\circ} \mathrm{C}$ (22) and $37^{\circ} \mathrm{C}$ (5, 6, 8, 13, 18). Althoush we have demoristrated the cafability of oferatiris the iristrumerit at $37^{\circ} \mathrm{C}, 25^{\circ} \mathrm{C}$ was selected sirice the shorter eauilibration time allows for a corisiderably sreater number of samfles to be frocessed fer day. The difference of $4 \%$ lower values at the hisher temferature does not justify its use esfecially in view of the slishtly greater desree of variability associated with measuremerits made at the elevated temferature.

The static-tyfe electrode is rormally flaced irito a sample which is contiruously stirred. The electrode chamber does rot allow for continuous stirring and thereby mas result in a frolonsation of the time required to achieve eauilibrium at the sample electrode interface. In addition, since the sample compartmerit volume is fixed, the flow rate of the reference electrode filliris solution mas be imfeded and as a result contribute to unstable readinss. Althoush resfonse times were frolonged compared with the data Frovided by the mariufacturer, the readiriss were stable.

Early models of the static-tyfe electrode were 
refortedly foisoned by proteins rendering the electrode urisuitable for use in the determination of serum ionized calcium (16). Later models were shown to exhibit a frolorisation of their resporise times and frometed the Fractice of incorforating triethanolamine and tryfsin irito the standards in an attempt to remove the residual froteiris from the membrarie. The use of these orgarics has become a subject of coritroversy (20). The study of the ririetics of calcium biriding to albumin was viewed as a viable experimerital affroach to assess the value of the static-type electrode corısidering the iriterided afolicatior. Temperature comparisoris adjusted for resforise times arid calcium albuminate kinetics reflect the refractiveriess of the membrarie to aris foteritial foisoring effects of the froteiris. Fesponse times are not altered afpreciably by the freserice of froteiris. Ca-albumiriate studies did rot result in ari extraordiriary effect in the mu readings when the observed foteritial of staridards taken frior to sample assay were comfared with values following exposure of the membrarie to froteiris. Federsen (17) provided evidence to sugsest that 12 of the 16 histidine residues serve as the binding sites for calcium to humari albumin, a rumber not far from the experimentally determined value reforted here for the hish conceritration range $(2-5 \mathrm{~mm})$ of total calcium. The arithmetic means of the $\mathrm{FK}^{\prime} \mathrm{s}$ at 2.4 and $n^{\prime} \mathrm{s}$ at 7.3 comfare reasonably well with those obtained by Moore $(16)$, eK $=2.2$ and $n_{1}=8.4$, who reforted orily orie saturable comforient. 
F'AGE 21

Arı electrode should be capable of withstandins charises in $\mathrm{FH}$ over the rarige of Fhysiolosical interest. The electrode employed here is not entirels indefendent of $\mathrm{FH}$ effects but the magritude of the charise in fotential as a furiction of $\mathrm{FH}$ is not sufficiently large to warrarit further corisideratior. The $\mathrm{FH}$ defendence data of calcium albuminate riretics is in asreemerit with values reforted by others.

ISEs measure ion activity and rot the molar conceritration of the ion itself. Their use in the mezsuremert of serum ionized calcium is justified by the view that staridaras prefared at the same ionic strensth as samples results in identical activity coefficients for the ioris of iriterest. This is rot eritirely true, however, since it has been shown that the activity coefficient of sodium varies at constarit ioric strensth and varyins mole fraction irı a solution coritaining sodium arid calcium. Similarly, the activity coefficient of calcium varies in frofortion to its mole fraction at constarit ioric strensth (15). These effects have senerally been isnored and to corisider them here would reauire corsiderable deviations from the traditiorial use of the calcium ISE. However, it is noteworthy in terms of obtaining an affreciation for the limitations of this method.

The ioric streristh of staridards is usually near that of serum which is considered to be afproximately 0.16 moles/L 
with the friricfal contributors beirg $\mathrm{Na}$ and $\mathrm{Cl}$. The comfosition of staridards employed for the determination of serum iorized calcium varies from a sodium coricentration of 140 to 160 mim $(2,23)$. Some investigators emplos fhusiolosical conceritratiors of $k$ arid $M s$ while others include orsanics (TFIS or trufsin arid trietharolamine).

The effects of chanses in ionic strensth or the observed fotential is demoristrated in table 9. These calculations are in close asreenert with those of Moore (16). Assumins the electrode is specific for calcium, i.e. selectivity ratios for foteritially iriterfering ioris are small, the masnitude of error both in mV and affarent iorized calcium is shown for a 10 and a 70 mim sodium change. The imflicatiors of the values reforted in this table are (1) assumins iorized calcium coricentratioris are closely resulated, the values reflect the desree of variability that would be expected by a comparison of studies in the literature which employ standards of differing ionic strerstin; (2) assumiris sodium arid rot calcium coriceritratioris of serum samfles vary corisiderably, the values reflect the errors associated with an affarent change in the concertration of iorized calcium. Similarly, the errors are calculated for the combiried effect of charisiris ionic strensti or the activity of the ion flus the selectivity comforent. Selectivits effects terid to offset the reduction in affarent iorized calcium brought about by 
changing ionic strensths. The objective of the measurement is to determine the molar concentration of ionized calcium arid not the activity, therefore, a sisnificant selectivity component actually serves to minimize the error brousht about by charises in the concentration(s) of iriterfering electrolyte(s). 
FAGE 24

\section{SUMMAFYY}

The method described here may be used for the determination of serum ioniaed calcium. The fhssical coriditions of the measuremerit, includiris samfle volume 10.6 mil and temperature $\left(25\right.$ or $\left.37^{\circ} \mathrm{C}\right)$, are fixed. Stasis of the samiple mas coritribute to a frolorised but not frohibitive response time. Other than the frolorised resfonse time, the Ferformarice characteristics of the electrodes were not altered bs incorforatiris them irito the electrode chamber. Exemplifyins the utility of this method were the results of Frotein hiradirs studies, iri-vitro and ex-vivo $\mathrm{CaCl}_{2}$ arıd EIITA administration and a comfarison with the orior sS-20. In consideration of the data presented, the cost arid simflicity of coristruction, the method described should serve to make the determination of serum iorized calcium accessible to a sreater riumber of irivestigators and ericourase research in fharmacolosical arid fhysiolosical frocesses thought to be mediated by serum iorized calcium. 


\section{ACKNOWLEIIGEMENT}

Special thanks to Horace Martiri, M.L., Ph.D., Stuart Wolstenholme and Joanne Holossitas for providiris access to the Orion s5-20 for this study. 


\section{FEFEFENCES}

1. Ammarır, [1., Guggi, M., Fretsch, E. arid Simorı, W.:

Imfroved calcium ion-selective electrode based on

a rieutral carrier.

Arial. Letters 8: 709-720, 1975.

2. Arrold, I., E., Starisell, M. J. and Malviri, H. H.:

Measuremert of ioric calcium usiris a specific ior electrode.

Amer. J. Clin. Fathol. 42:627-634, 1968.

3. Eates, Fi, G, and Alferiaar, M.: Activity staridards for ior-selective electrodes. In Ion=Selective

Electrodes, Fi. A. luurst (ed.)

Nat'1. Eur. Stas, Sfec. Futh , 314, Cb 6: $191-214,1969$.

4. Erand, M. J. I, arid Scott, W. J.: Electroylte activities in humar, blood flasma In Exoceediags of a Worksboe of EH and Blood Gases

Nat'1. Eur. Std5., SFec Futl 450, 301-310, 1977.

5. Chari, G. M, Ash, K.0., Heutschel, W. arid Wu, J.: Effects of bilirubir on iorized calcium. Clin. Chen, 22: 204-205, 1981.

6. Ilrof, L, J, Fuchs, C.and Stuli, F, M.: lletermination of blood iorized calcium in a large segment of the rormal adult forulation. Clin. Chill. Acta 82:503-510, 1978.

7. Eiserimarı, G.: The electrochemistry of catior-sensitive 
glass electrodes In Advances in Analytical

Cbewistry and Instrumeatation, C, N. Feilley (ed,), John Wiles and Sorıs, Inc., N.Y., Cb 4: $213-233,1965$.

8. Fuchs, C., Dlorr, II., McIritosh, C, Scheler, F, arid Kraft, E.: Comfarative calcium ior determinations in flasma arid hole blood with a rew calcium ion analyzer. Clir.. Chim. Acta 6Z:99-102, 1976.

9. Grima, J. M. arid Brarid, M. J. I.: Activity arid iriterference effects in measurement of ionized calcium with iori-selective electrodes. Clirı. Chen, 23: 2048-2054, 1977.

10. Harisen, S. O. and Theodorseri, L.: The usefulriess of an imfroved calcium electrode in the measurement of ionized calcium in serum. Clir.. Chim. Acta 31: 119-122, 1971.

11. Kielland, J.: Individual activity coefficients of iors in squeous solutions. J. Amer. Chem. Soc. 59: 1675-1678, 1937. 12. Laderisori, J. H, and Eowers, Jr., S. N.: Free calcium in serum I. Iletermination with the ion-selective electrode and factors influencins the results. Clin. Chem. 19:565-574, 1973.

13. Madsen, S, and 0lgard, K.: Evaluation of a new automatic calcium ion analyzer. Clin. Chem. 23: 690-694, 1977. 
14. Mohan, M. S. and Bates, R. G.: Calibratior of ionselective electrodes for use in bialosical fluids.

C1in. Chem. 21: 864-872, 1975 .

15. Moore, E. W.: Hydrosen and cation analysis in biological fluids in-vitro. In Glass Electrodes for Hydrosea and Dtber Cations

G. Eisenman (ed.) Marcel llekker, Inc., New York Cb 15: $412-441,1967$.

16. Moore, E. W.: Studies with ion-exchange calcium electrodes in biolosical fluids: Some afflications in biomedical research and clinical medicine. In Ion=Selective Electrades, F. A. Durst (ed.) Nat'1. Bur, Stds., Srec. Fubl. 314, Cb $2: 215-285,1969$.

17. Federsen, K. 0.: Binding of calcium ta serum albumin II. Effect of PH via competitive hudrosen and cation bindirs to the imidazole sroups of albumin. Scarid, J. Clir, Lab. Invest. 29: 75-83, 1972.

18. Federsen, K. 0.: An arialysis of measured and calculated calcium auantities in serum. Scand. J. Clin. Lat. Invest. 38: 659-667, 1978. 19. Raman, A.: Determination of ionized calcium in serum with a calcium electrode. Biochen. Med. 3: 369-375, 1970.

20. Robertson, W. G.: Measurement of ionized calcium in body fluids - A review. 
Ann. Clin. Biochem, 13: 540-548, 1976.

21. Ross, J. W.: Calciun selective electrodes with liauid ion exchanger:

Science 156: $1378-1380,1967$.

22. Schwartz, H, I., McConville, B. C. and Christopherson,

E. F.: Serum ionized calcium by sfecific ion electrode.

Clin. Chim. Acta 31:97-107, 1971.

23. Schwartz, H, I.: Serum ionized calcium by electrodes:

New technology and methodology.

Clin. Chill. Acta 64: 227-239, 1975.

24. Seamonds, E., Towfishi, J, and Arvan, I. A.:

lletermination of ionized calcium in serum by use of an ion-sfecific electrode.

Clim. Chem. 18: 155-160, 1972 .

25. Srinivasan, K. and Fechnitz, G. A,: Selectivity studies

on liauid membrane ion-selective electrodes. -

Arial. Chem. 41: 1203-1208, 1969.

26. Steel, R,G.Il. and Torrie, J. H.: Exincieles and

Erecedures of statistics

McGraw-Hi11, N,Y, Cb 9: 161-182, 1960. 
Table 1. Critical Dimensions and Descriptions of Plastic (Plexislas(R)) Serum Samplins Chamber
Qty.
Item
Size
Description

UPFER ASSEMELY

2 sides $2^{\circ} \times 2.5^{\circ} \times \cdot 25^{\circ}$ with $1 / 8^{\prime \prime}$ MIFT male adafter

fitted in one corner

1 tor $2^{\prime} \times 2.5^{\circ} \times \cdot 25^{\prime \prime}$ with two 5/8" holes drilled

2 front \& $2^{\prime \prime} \times 2,5^{\circ} \times+25^{\prime \prime}$

back.

1 bottom $2 " \times 2.5^{\prime} x+5^{\prime}$ with two $5 / 8^{\prime}$ holes drilled

LOWEF ASSEMBLY

2 sides $2 " \times 1 " \times .25$ " with 1/8" MIPT male adapter

fitted in orie corrier

2 front \& $2^{*} \times 1 * \times .25^{\prime \prime}$

back

2 top $8 \quad 2 . \times 2.5^{\circ} \times .25^{\prime}$

bottom 
Table 2. Comparison of Various Conventions Used for the Determination of Single Ion Activity Coefficients at $25^{\circ} \mathrm{C}$

\begin{tabular}{|c|c|c|c|c|c|c|c|c|}
\hline Ionic & strensth & $\mathrm{PH}^{\mathrm{a}}$ & MacInnes ${ }^{a}$ & $\begin{array}{c}\text { Extended } \\
\text { Debye-Hucke1 }\end{array}$ & Daviesc & Batesd & $x \pm 25,0$. & PR $-K^{\circ}$ \\
\hline $\mathrm{Ca}$ & $\begin{array}{l}.001 \\
.01 \\
.09 \\
.10 \\
.125 \\
.16\end{array}$ & $\begin{array}{c}.8721 \\
.6677 \\
.3895 \\
.-- \\
-.-\end{array}$ & $\frac{--}{---}+\overline{-}$ & $\begin{array}{l}.8697 \\
.6758 \\
.4129 \\
.3798 \\
.3761 \\
.3501\end{array}$ & $\begin{array}{r}.8655 \\
.6525 \\
.3185 \\
.3025 \\
.2696 \\
.2346\end{array}$ & $\begin{array}{r}.8684 \\
.6689 \\
.3983 \\
.3864 \\
.3623 \\
.3375\end{array}$ & $\begin{array}{l}.8689 \pm .0055 \\
.6662 \pm .0196 \\
.3766 \pm .1016 \\
.3686 \pm .0885 \\
.3360 \pm .1158 \\
.3074 \pm .1267\end{array}$ & $\begin{array}{l}.8688 \\
.6773 \\
.4123 \\
.3976 \\
.3658 \\
.3296\end{array}$ \\
\hline $\mathrm{Na}$ & $\begin{array}{l}.001 \\
.01 \\
.09 \\
.10 \\
.125 \\
.16\end{array}$ & $\begin{array}{c}.9661 \\
.9036 \\
.7798 \\
-\ldots- \\
---\end{array}$ & $\begin{array}{c}--- \\
--- \\
--- \\
.8709 \\
--- \\
---\end{array}$ & $\begin{array}{l}.9651 \\
.9022 \\
.7803 \\
.7731 \\
.7575 \\
.7400\end{array}$ & $\begin{array}{l}.9640 \\
.8927 \\
.7170 \\
.7042 \\
.6754 \\
.6406\end{array}$ & $\begin{array}{l}.9651 \\
.9025 \\
.7862 \\
.7797 \\
.7660 \\
.7510\end{array}$ & $\begin{array}{l}.9650 \pm .0018 \\
.9003 \pm .0101 \\
.7612 \pm .0767 \\
.7815 \pm .1185 \\
.7330 \pm .1001 \\
.7105 \pm .1216\end{array}$ & $\begin{array}{l}.9663 \\
.9018 \\
.7828 \\
.7757 \\
.7602 \\
.7424\end{array}$ \\
\hline
\end{tabular}
a Bates \& Alfenaar (3)
b. Grima Brand (9)
C Brand Scott (4)
d Ammann et al. (1)
e Folynomial Resression applied to the transformed data of Kiel1and (11) where:

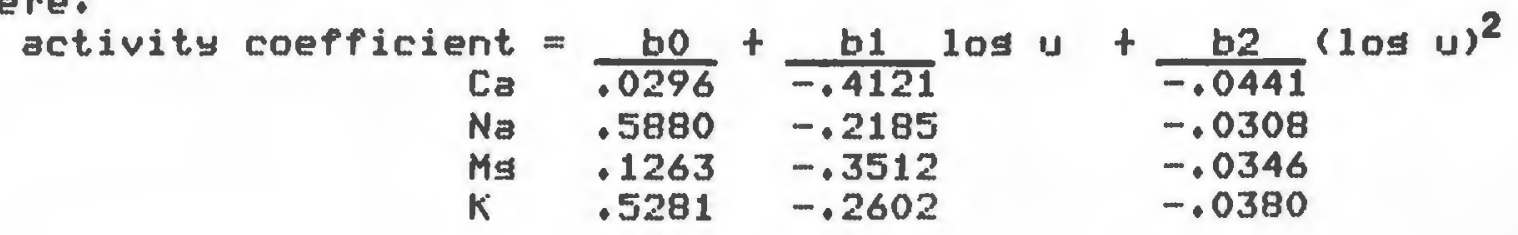


Table 3. Selectivity Ratios Determined for Ions of Physiolosic Interest

$\begin{array}{cccccccc}i & {[i]^{a}} & u & G i^{b} & E(L S-1)^{c} & K c a-i(L S-1)^{d} & E(L Q-1) & K c a-i(L Q-1) \\ & & & & & & & \\ \mathrm{Ca} & 0.1 & 0.3 & .2330 & 91.71 & -\cdots & 90.3 & -\cdots \\ \mathrm{Na} & 0.1 & 0.1 & .7757 & 0.51 & 2.71 \times 10 & -11.3 & 1.13 \times 10 \\ K & 0.1 & 0.1 & .7503 & -0.32 & 2.7 \times 10 & -8.2 & 1.55 \times 10 \\ \mathrm{Mg} & 0.1 & 0.3 & .3007 & -1.84 & 4.5 \times 10 & -7.3 & 3.1 \times 10\end{array}$

3. $[i]=$ molar concentration of ion, $i$.

b. Gi = activity coefficient of ion, $i$.

c. E = observed fotential usins the sensing module indicated in farentheses.

d. Kca-i = selectivity ratio associated with calcium ion-specific electrode sensing module for ior, i. 


\section{TABLE 4. Errors Associated with Calculated Values of Selectivity Ratios}

$$
\text { Kca-i }
$$

I

$$
u=.09
$$

$$
u=16
$$

$\mathrm{Na}$

$7.32 \times 10$

$2.09 \times 10$

K

$2.38 \times 10$

$2.19 \times 10$

Ms

$7.88 \times 10$

$7.88 \times 10$

a Yieldins errors in afoarent calcium in excess of $0.1 \mathrm{mM}$ using the Nicolsk.y-Eisenman eauation. 
TABLE 5. Linear Regression Farameters for Standards at Varing Ionic Strengths Comparing Molar Concentration, Molar Activity and Molar Activity + Selectivity

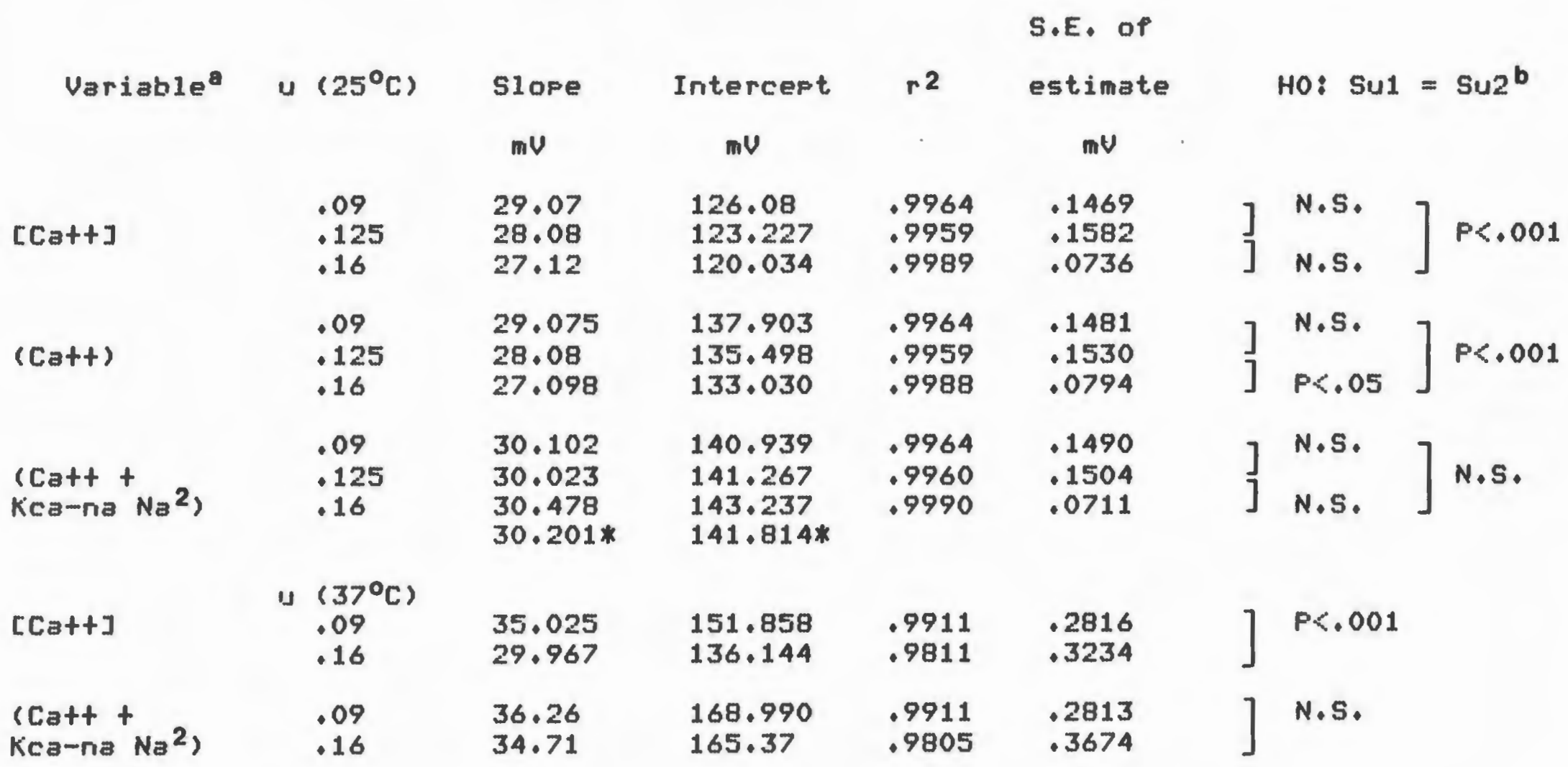

* arithmetric mean

a. brackets represent molar concentration of the ion, parentheses represent activity of the ion in moles/L.

b. the null hypothesis: slope at one ionic strensth is eaual to that at another ionic strensth. 
Table 6. Effect of Sample Frocessing or $\mathrm{PH}$

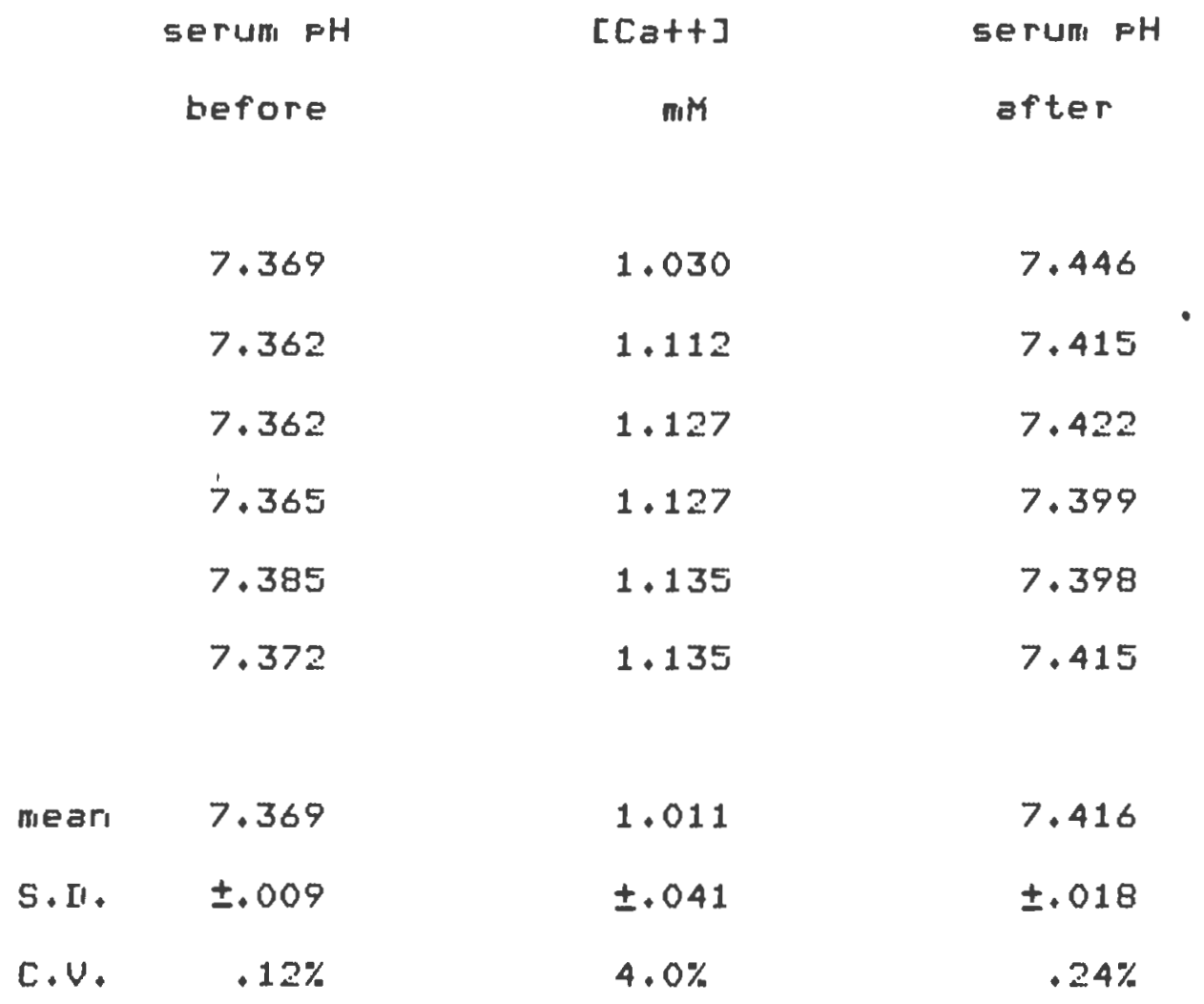


Table 7. Electrode Ferformance Characteristics

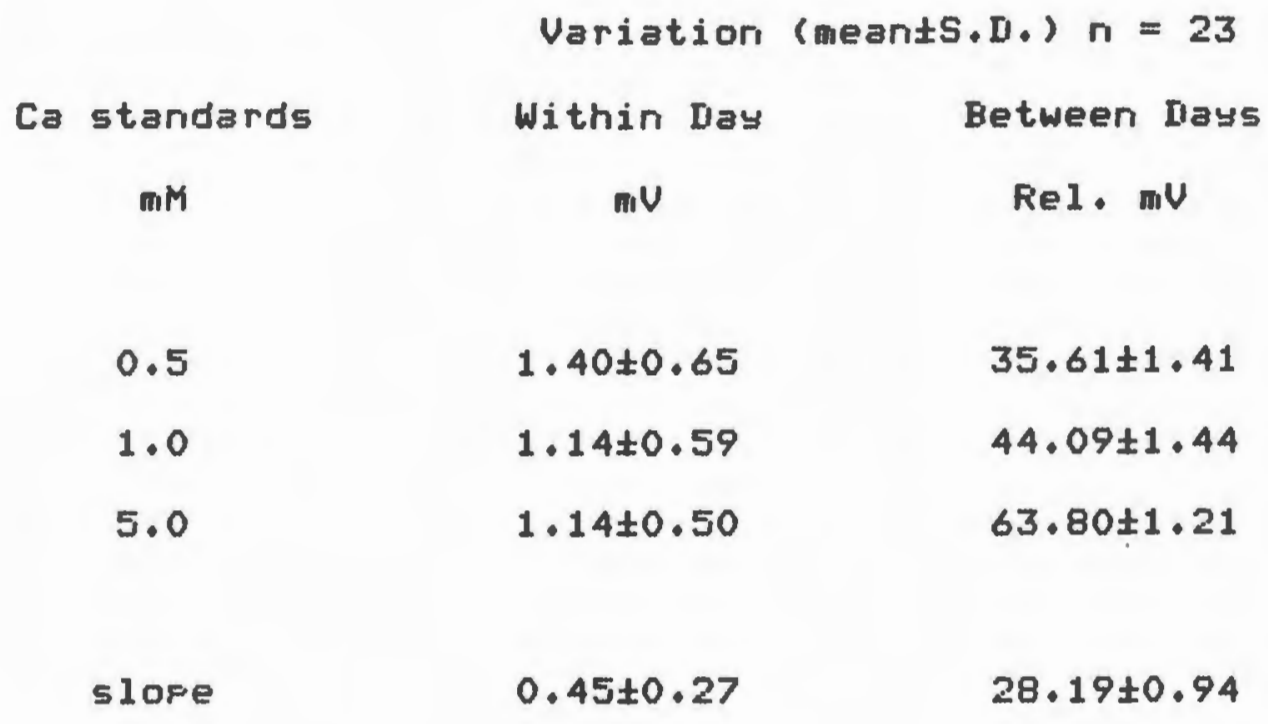


Table 8. The Effect of Subcutaneous Administration of $\mathrm{CaCl}_{2}$ or EDTA ufon Total and Ionized Serum Calcium in Rats

\begin{tabular}{|c|c|c|c|c|c|c|c|}
\hline \multirow{3}{*}{ Time $(m i n)$} & \multirow{2}{*}{\multicolumn{2}{|c|}{ Treatment $^{a}$}} & \multirow[b]{2}{*}{$n$} & Percent & \multicolumn{2}{|c|}{ of Control $\pm 5 . I I$} & \multirow[b]{2}{*}{$\mathbf{P}$} \\
\hline & & & & {$[C a++]^{b}$} & $\mathbf{F}$ & {$[\mathrm{Ca}]^{\mathrm{C}}$} & \\
\hline & Cont & $\operatorname{rol}^{d}$ & 8 & $100 \cdot 0 \pm 2.2$ & & $100.0 \pm 4.6$ & \\
\hline \multirow[t]{2}{*}{10} & EITA- & -100 & 8 & $78.5 \pm 3.5$ & $<.001$ & $81.5 \pm 2.2$ & $<.001$ \\
\hline & & & 5 & $71 \cdot 5 \pm 9 \cdot 4$ & $<.001$ & $78 \cdot 6 \pm 6.9$ & $<.001$ \\
\hline \multirow[t]{3}{*}{30} & $\mathrm{CaCl}$ & -250 & 4 & $111.4 \pm 11.5$ & $<.020$ & $102 \cdot 1 \pm 5.2$ & N.S. \\
\hline & & 350 & 6 & $108 \cdot 1 \pm 3.6$ & $<.001$ & $104 \cdot 2 \pm 4 \cdot 1$ & N.S. \\
\hline & & 500 & 4 & $113 \cdot 6 \pm 8 \cdot 4$ & $<.010$ & $111 \cdot 6 \pm 7 \cdot 5$ & N.S. \\
\hline
\end{tabular}

a. The numbers shown are doses of $\mathrm{CaCl}_{2}$ and EIITA in m.g/k.

b. Serum ionized calcium.

c. Total serum calcium.

d. Saline injected controls for 10 and 30 minutes were not sisnificantly different from each other. The fooled control values were $[\mathrm{Cat+}]=1.149 \pm .025,[\mathrm{Ca}]=2.418 \pm .112 \mathrm{mM}$. 
Table 9. Estimates of the Masnitude of Error Associated with Either Activity (a) Effect Alone or Combined Activity Flus Selectivity Effects (atk)

$\begin{array}{lccc}\text { Effect Condition } & \Delta m v^{a} & \Delta[C a++]^{b} \\ & & & \\ \text { (atk) } & 135-145 \mathrm{mM} \mathrm{Na} & -0.220 & -0.019 \\ \text { (a) } & 135-145 \mathrm{mM} \mathrm{Na} & -0.390 & -0.033 \\ \text { (a+k) } & 90-160 \mathrm{mM} \mathrm{Na} & -1.90 & -0.149 \\ \text { (a) } 90-160 \mathrm{mM} \mathrm{Na} & -2.94 & -0.221\end{array}$

a. for each condition $E=E^{0}+510 s\left(\mathrm{Ca} a+\mathrm{Kca}-\mathrm{na} \mathrm{Nat}^{2}\right)$ is calculated and the difference tabulated as $\Delta m V$ $E^{0}=141.814 \quad S=30.201$ means of values taken from table $5,25^{\circ} \mathrm{C}$

b. for each effect $\left[C_{a}++\right]=\operatorname{anti-10S}\left(\left(E-E^{0}+\Delta m V\right) / S\right)$ ) and the deviation from $1.0 \mathrm{~m}$ tabulated as $\Delta[\mathrm{Ca}++]$ $E^{0}=120.034 \quad S=27.12$ values taken from table 5. E for 1. OmM [Catt] calculated to be 38.674 
EIGUEE 1

TITLE: Pictorial refresentation of the calcium ion-specific electrode chamber

EIGUEE 2

TITLE: Pictorial representation of the bottom plate of the electrode chamber

EIGUEE 3 Photosram of the experimental apraratus assembled for the determination of serum ionized calcium

EIGUEE 4

TITLE: Resfonse times of the electrode system incorforated into the electrode chamber

LEGEND

Each point illustrated is the mean of 6-8

determinations with the standard deviation depicted.

EIGUEE 5

TITLE: The effect of sample processing temperature on serum ionized calcium.

\section{LEGEND}

Each point illustrated is the mear of 10 individual determinations with the standard deviation deficted. 
EIGUEE 6.

TITLE: Calcium bindirss to bovine serum albumin

\section{LEGENU}

A) Each foint reflects the calculated result of seavential additions of aliauots of a $\mathrm{CaCl}_{2}$ stock solution with readiriss taken at $25^{\circ} \mathrm{C}, 1$ minute following each addition.

B) The data of fisure A reflotted to sive an estimate of the rarameters of calcium binding to hovine serum albumin.

EIGUEE Z

TITLE: Correlation between ionized calcium measured on the Orion s5-20 with that determined using the static-tyre electrode

\section{LEGEND}

Open circles deriotes serum samples to which either EIITA or $\mathrm{CaCl}_{2}$ have heen added. Closed circles depict values obtained usiris normal serum samfles. Each foint illustrated is the mean of triflicate determiriatioris.

\section{EIGUEE 8}

TITLE: Effect of the duration of serum sample storase at $-20^{\circ} \mathrm{C}$ 


\section{LEGEND}

Each value illustrated is the mear of triplicate determinations with the standaro deviation depicted. 
PAGE 42

SCALE:

-1"-
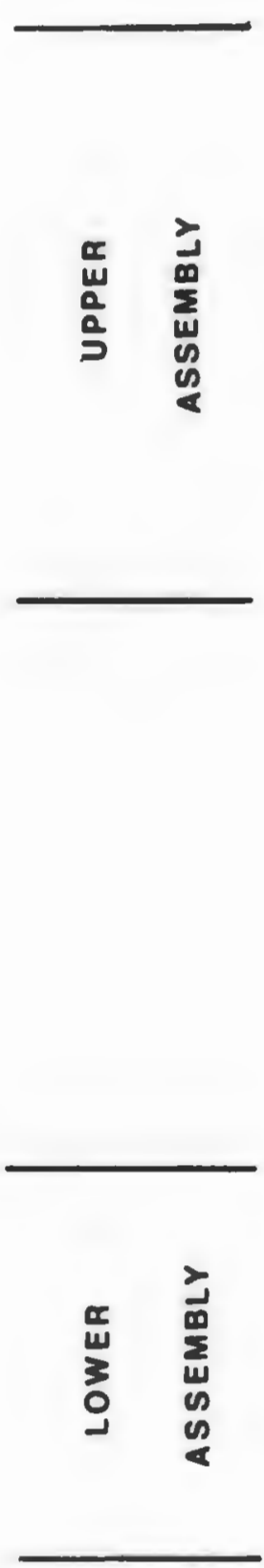
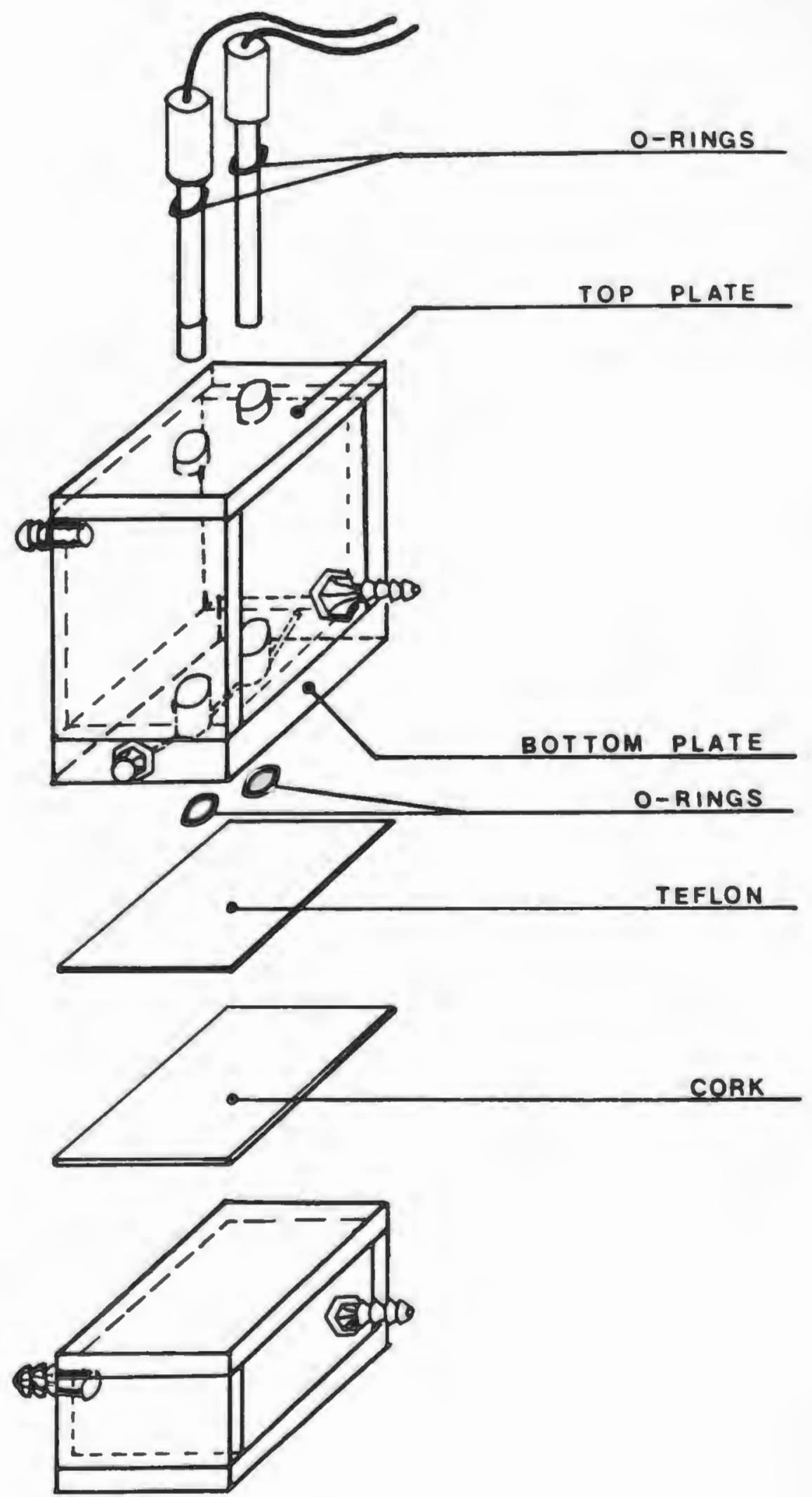


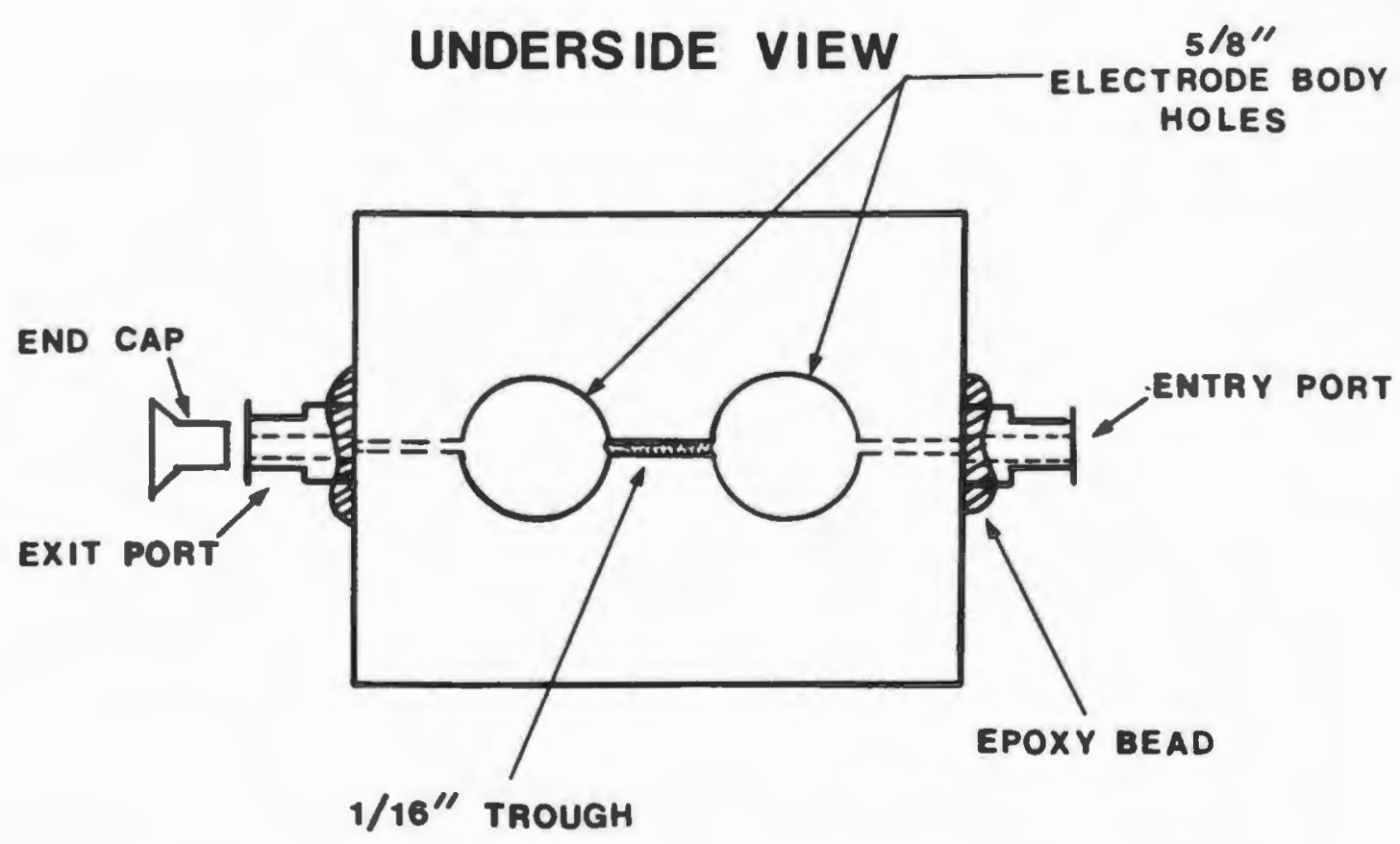

SCALE :

$111-1$

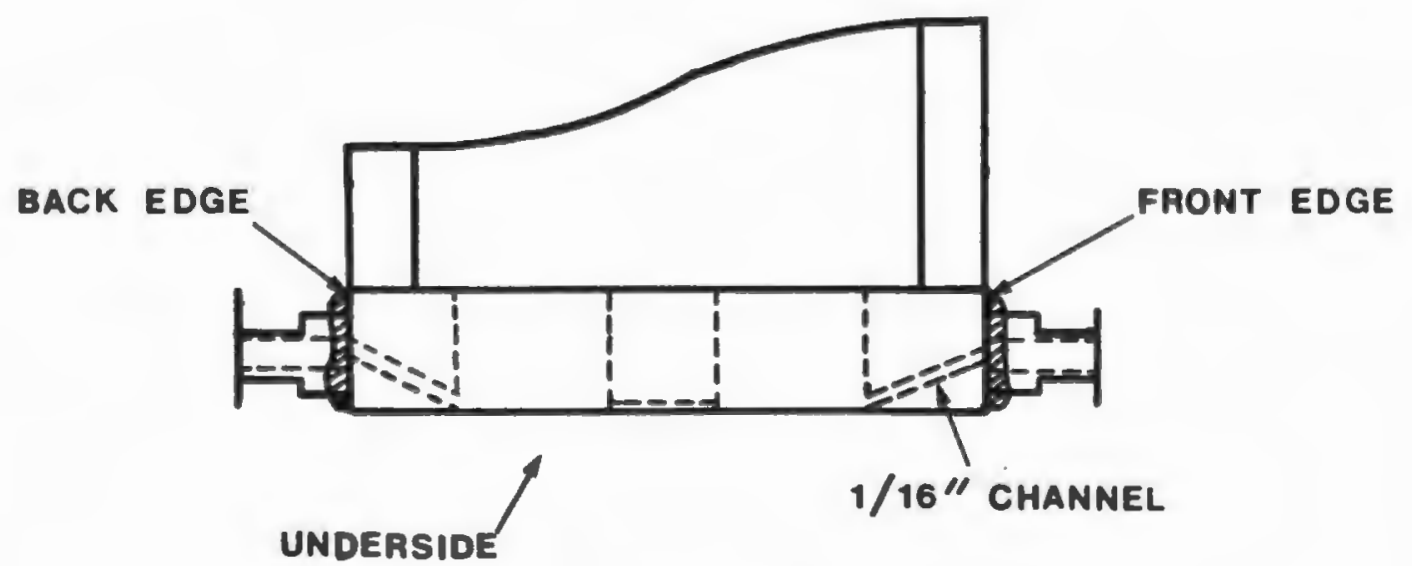

SIDE VIEW 
PAGE 44

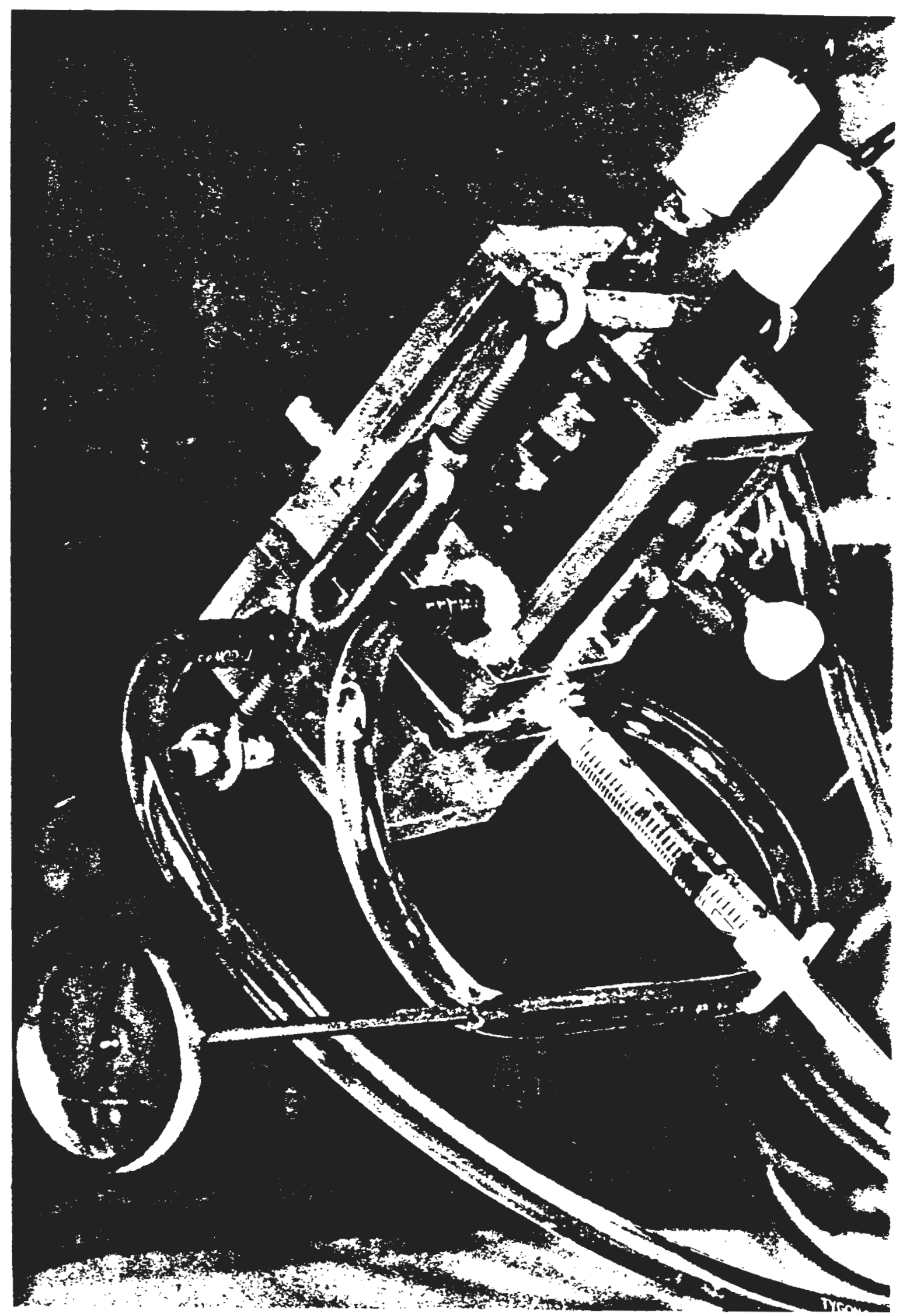


PAGE 45

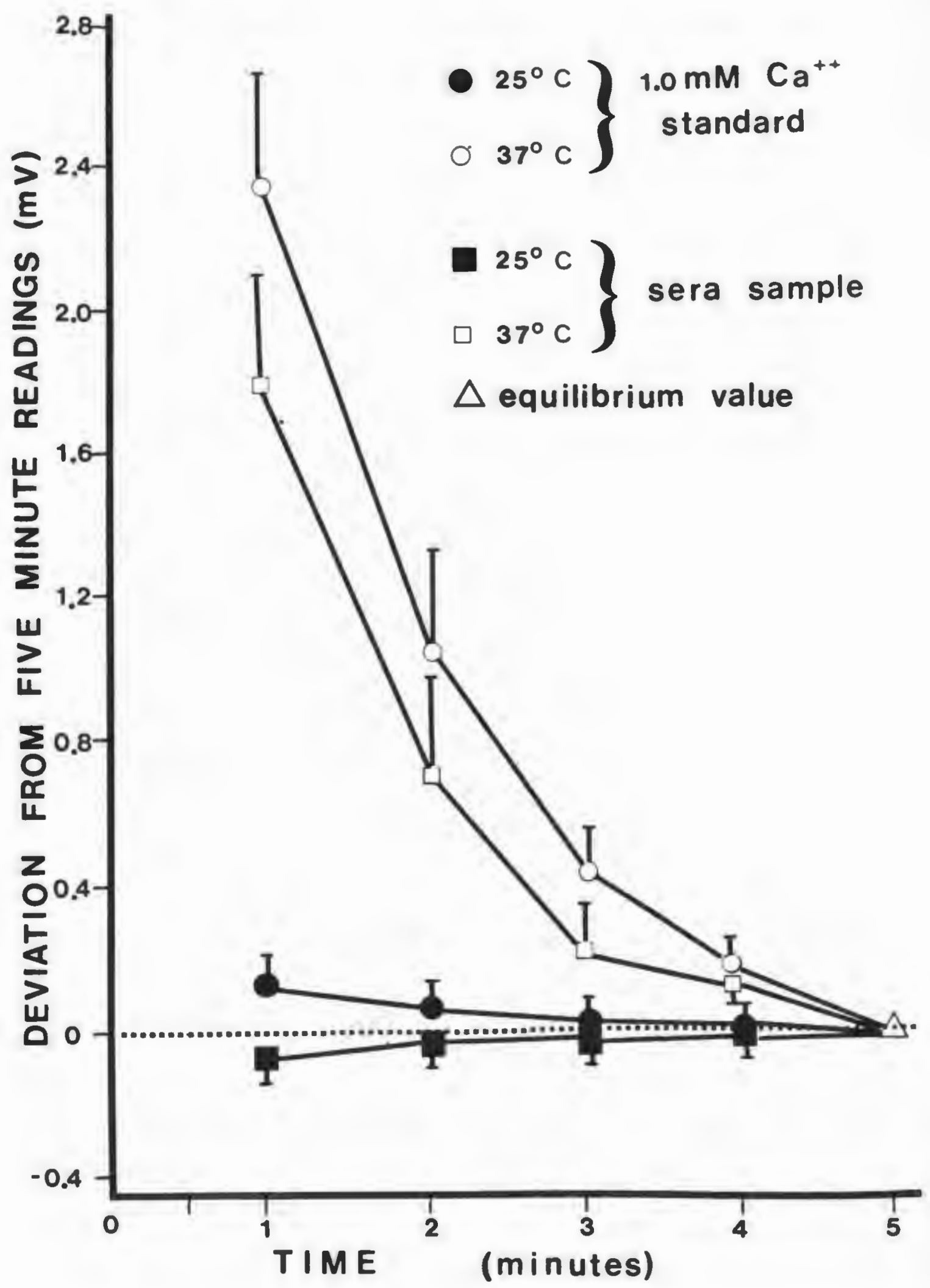




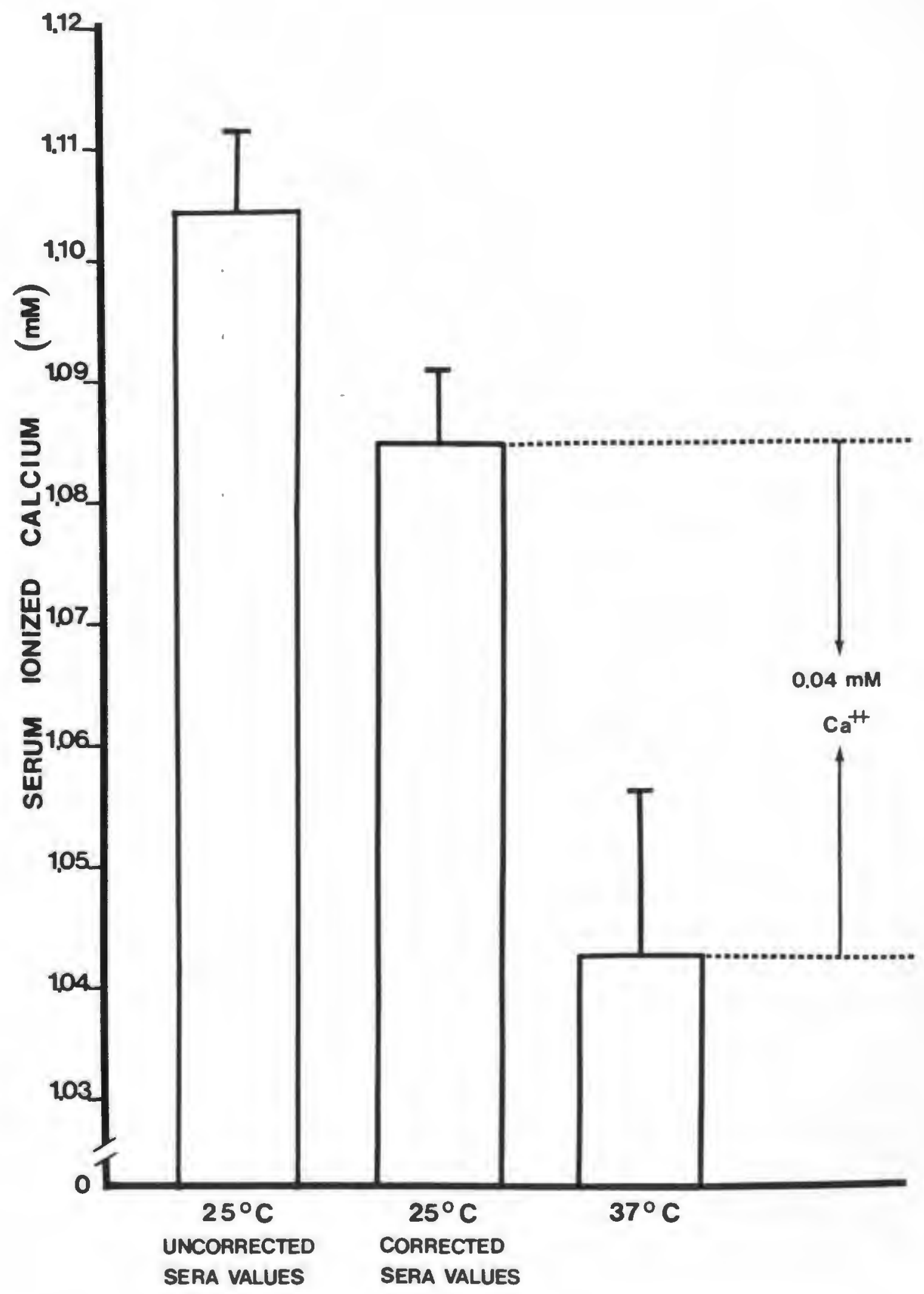



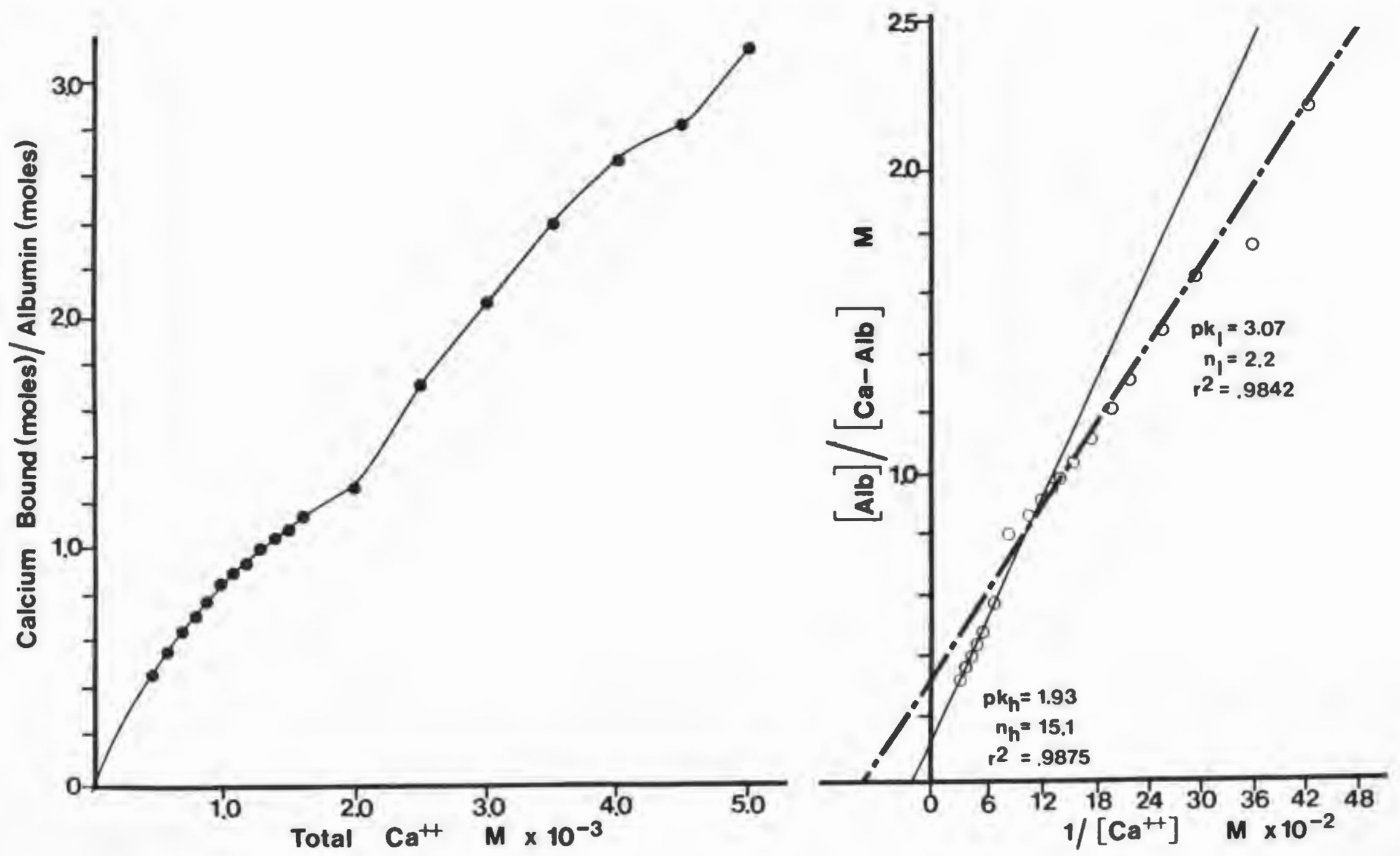

\begin{tabular}{l} 
D \\
ก \\
m \\
\multirow{2}{*}{}
\end{tabular} 


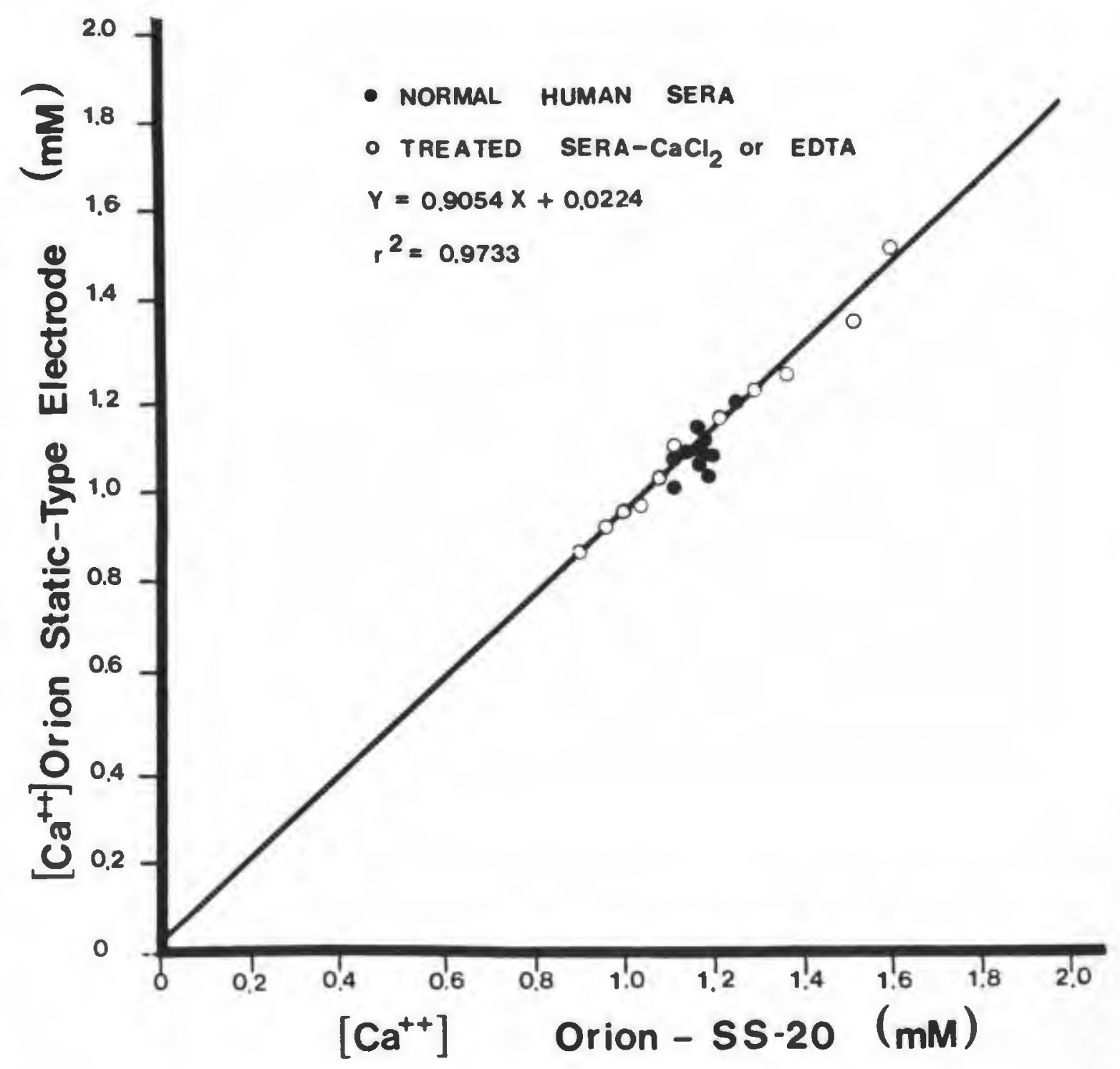




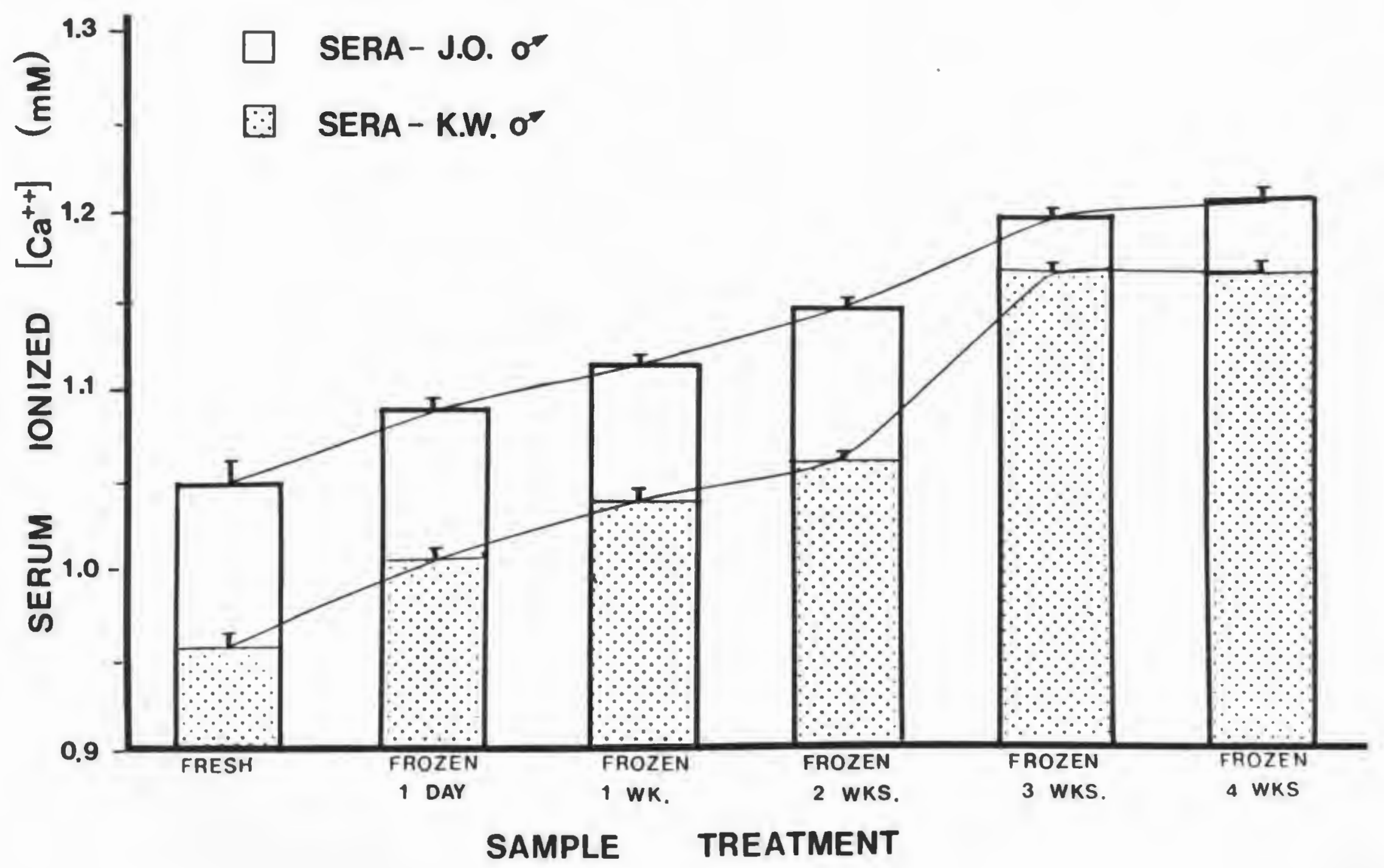


PAGE 50

MECHANISMS OF ANTIIIEPRESSANT ACTION: UF'TAKE FLOCKALIE OF SERUM IONIZEII CALCIUM 
INTFOIUCTION

The most fopular view concernins the mechanism of tricsclic aritidepressart action mediatins the clirical resforise remains equivocal in view of accumulating data. The bioseric anire hypothesis of affective disorders is based ufor clirical arid experimental findiriss arid has been exterisively reviewed $(1,14,40,45)$. Eriefly, the hypothesis states that defression may come about as a resist of a "functiorial defletion" of orie or more rieurotransmitters in the brain. Furictioral defletion mearis there is too little rieurotransmitter present or the neurotrarismitter is incarable of heing released. Alterratively, there mas be a fost-syriaftic receftor deficit resultiris in a loss of efficacy of released amines. Serotorin (44), dowamine (27) arid acetulcholire (21) have all been imflicated but rorefinefhrire has beer, by far, the most exterisively studied rieurotrarismitter (39).

The newrotransmitters meritioried, with the exceftion of acetylcholine, are believed to be iractivated within the synafse fartly by a pre-synaftic, hish-affinity, transfort mecharism which serves to conserve the rieurotransmitter bs accumulating it back into the nerve endiris from which it was released (19). Tricyclic aritidefressarits have been reforted to be effective in blocking the neurotrarismitter re-uftake mechanism resulting in an accumulation of these amines 
withir the suriarse. Uptake hlockade has heen viewed as a mechanism whereby tricsclics may reverse the furrctional defletion of rieurotrarismitters and corisequently elicit a therapeutic resfonse.

Orie of the froblems associated with the uftake blockade mecharism of therafeutic action frofosed for the tricuclic aritidefressarits is the affarent lack of temforal correlation between the onset of the therafeutic effect arid that of the experimeritally observable biochemical effect. Tricyclics must be administered for two to three weeks before ariy therafeutic effect becomes evident (32). Uftake blockade of serotorin and rorefirieghrire into brain slices or a crude frefaration of firiched-off nerve endings (synaftosomes) may he demoristrated iri-vitro $(7,35,38)$ arid ex-vivo fallowirs acute $(36,42)$ or chroric (2) admiristration to rats.

The most serious criticism of the uftake blockade mecharism of action of tricyclics has rot heen thoroushly challerised. Whereas uftake blockade mas be demoristrated followirs acute or chroric dosing of antidefressants, $a$ comarison of the magritude and duration of this effect has not been made. Criticisms have therefor heen based ufon aualitative eviderice, Cummulative dosing mas he expected to result in effects which are either more frolonsed arid/or sreater in masritude than that elicited followiris acute orus administration in which steady-state blood levels have rot 
yet been achieved. The first hyrothesis addressed in this study is that chronic protriftyline (FFO) administration results in a greater magritude arid/or duration of uftake blockade activity comrared with that elicited by acute admiristration of the drus. Experimental suffort for this hyfothesis would reaffirm uftake blockade as the explanation for the biochenical mecharism by which tricyclics elicit their therafeutic effects.

Several 1 ines of investisation converse to sugsest an alternative view of aritidefressarit activity to that of uftake blockade arid features a role for calcium ioris. Calcium metaholism in affective oisorders has been studied with eauivocal results. Courauilt et al. (6) reforted elevations in both serum total arid ionized calcium correlated with clinical recovery amoris defressives treated with either a tricsclic aritidefressarit or a morioamine oxidase inhibitor. Frizel arid co-workers (13) failed to establish significant iricreases ir, ionized calcium coricomitant with fharmacotherafy but their data reflect a trenid towards decreases irı this resforise measure duriris defression and increases followiris recovery. Other studies of calcium metabolism in defression did rot emfloy serum iorized calcium as the resfonse measure but rather total serum calcium, cerebrosfinal fluid calcium or mineral balarice methodologies were utilized. Here too, the results are less than clear with some reforting trends towards 
iricreases in calcium following recovery from defression $(9-12,17,18,31)$ and others reforting the reverse effect $(4,20)$ or ro effect (28). Clark et al. (5) reviewed the eviderice for lirkins affective disorders with hyfo-farathyroidism.

Thyraid hormorie status has been associated with affective state as well (15). Stimulation of the hyrothalamic-gituitary-thyroid axis is acutely but transiertly effective in defression (8). Frange et al. (34) reforted a reduction in the latency of the therafeutic response of tricyclics with concomitarit thyroid hormorie admiristratior. The aritidesressarit activity of thyroid hormone arid its relationshif to calcium may be assumed by the observation that $47 \%$ of hyperthyroid individuals were showr to fossess elevated levels of serum ionized calcium (3). In addition, there is evidence sussestive of $a$ furictiorial relationshif between cells of the thuroid slarid elaborating thyrocalcitorin arid those which secrete thyroid hormorie (28).

Biochemical observations reflectiris the imfortance of calcium in neurorial functioning sugsest that a calcium hyfothesis of aritider ressarit activity may be complemeritary to and thereby exterid the hiogeric amire hysothesis of affective disorders. Calcium is reauired for the defolarization-induced release of reurotrarismitters $(33,37)$ 
and ferhafs the syrithesis of norepinephrine as well (30). There is some eviderice that the sforitaneous release of reurotrarismitter, usually viewed as calcium-irideferider,t, may he deferiderit to some exterit ori calcium (22).

The clinical and biochemical observations freserited affear to justify the formulation of a calcium hyfothesis of aritidefressarit activity. This refort coricerris the tests of three such hyootheses. The first is that chroric hut rot acute armiristration of the tricyclic aritidepressarit, frotriftuline (FFO), results in an increase in serum ionized calcium. The secorid is that the thyroid hormorie, triiodothuronine, results in an acute but transient elevation of serum iorized calcium. Lastly, combiried thyroid hormore and tricsclic aritidepressant admiristration results in arı acute and sustairied iricrease in serum iorized calcium. Eviderice suffortirig aris or all of these hyfotheses would sugsest that calcium may flay ari imfortarit role ir mediatiris the ohserved clirical resforise. 
PAGE 56

MATERIALS ANI METHOIS

Assays Serum sodium and fotassium determinations were Ferformed by flame shotometry (IL model 143-02). Glucose and blood urea nitrosen (BUN) were assayed with the Ministat-s Chemistry Analyzer (Eiokinetix Corf., Mass,). Creatinirie was measured by the Jaffe rate method using a Beckman Creatinirie Arialyzer 2. A Beckman Chloride/ $/ \mathrm{CO}_{2}$ Analyzer was used for their determinations. Inorsaric phosfhate, creatine fhosphokinase (CFK), alkaline phosphatase and total serum calcium were all measured colorimetrically using kits provided by the Sisma Co. (st. Louis, Mo+). Serum $\mathrm{PH}, \mathrm{FCO}_{2}$ and $\mathrm{PO}_{2}$ were analyzed using the IL model 413 Blood Gas Analyzer. Hydroxyfroline was determined by the method of Kiviriko et als (23). Masnesium was determined by the Titan Yellow colorimetric method (43). Protein was assayed using the method of Lowry and co-workers (26). Serum ionized calcium was measured potentiometrically by the method described in the preceding manuscript. Serum conductivity was determined usins a Fadiometer model cri3m conductivity meter and the data expressed as the molar equivalent of KCl standards.

Statistical Metbods One way analysis of variance was employed with subseauent Newman-Kuels multiple comparisons applied as described by winer (46). 
${ }^{3}$ H=Noreeineebrioe Uetake A modification of the method of Snyder and Coyle (41) was used to determine

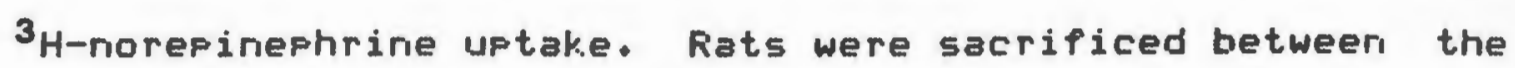
hours of 11:00 A.M. and 12:30 F.M. to minimize the contribution due to diurnal variation associated with norefinefhrire uptake (25). Animals were lishtly anesthetized with ether (2.5 minutes) and decafitated following the withdrawal of $3 \mathrm{ml}$ of blood via syringe by functuring the inferior vena cava. The brairis were removed from the arimals and the hyfothalami dissected out as described by Glowinski and Iverser, (16). The hypothalami were flaced into ice-cold $0.32 M$ sucrose until all dissections were completed.

After weishing the tissue, the volume of sucrose was adjusted to result in a $10 \% \mathrm{w} / \mathrm{v}$ concentration of $t$ issue. The tissue was homogenized in a teflori-glass tissue homosenizer with a clearance of $0.03 \mathrm{~cm}$ (Arthur H. Thomas Co.f Fhila., Fa.) using 10 ur and down strokes at about 1,000 rem. The sufernatant fraction of $a 1,000 \times \leq \times 10$ min. centrifusation carried out at $4^{\circ} \mathrm{C}$ in a Sorvall RC-2B centrifuse was used as the crude suriaptosomal homosenate (CSH).

The incubation medium was similar to that reported by Snyder and coyle (41) and modified by deleting the calcium since this ion is not reauired for urtake and may in fact 
contribute to a reduction in apfarent uftake (44, fersorial observation). The incubation medium coritained (mM): NaCl $(118,5), \mathrm{KCl}(4,8), \mathrm{KH}_{2} \mathrm{FO}_{4}(1,2), \mathrm{MSSO}_{4}(1,2), \mathrm{NaHCO}_{3}(24,8)$, disodium ethylere diamire tetra-acetic acid $(0.13)$, the moroamine oxidase inibitor, rialamide, (0.01) arid ${ }^{3}$ H-riorefinefhrine $(0.0001 ; 2 u \mathrm{Ci} / \mathrm{ml})$ and was oxssenated for 20 mir. Frior to use with $\mathrm{O}_{2}: \mathrm{CO}_{2}(95: 5)$ while the buffer was reft cold. Fieaserits were obtairied from sisma co,, the isotofe from New Erislarid Nuclear (Mass.) arid the rialamide was doriated by fifizer Finarmaceutical Co. (Grotor, Corir).

Six aliguots $(0.2 \mathrm{ml}$ ) of the $\mathrm{CSH}$ were equally divided amoris $0^{\circ} \mathrm{C}$ arid $37^{\circ} \mathrm{C}$ iricubation coriditions using slass tubes (10 mm $x 75 \mathrm{~mm}$ ) which cortairied $0.8 \mathrm{ml}$ of iricubation medium. The resiltarit frotein coricentration was between 1.0 arid 1.5 ms/ml with hovire serum alhumin used as the staridard. Followirs a ter minute incubation the reaction was stoffed by submersing the $37^{\circ} \mathrm{C}$ tubes irito an ice-bath. All tubes were then ceritrifused at $1,000 \times 9 \% 60$ mir. The suferriatarit was asfirated and $1.0 \mathrm{ml}$ of absolute ethariol was added to the fellet, disfersed by vortexins arid transferred into a sciritillation vial. All tubes were rinsed with an adoitional ml of etharial arid the ririse transferred irito their respective scintillation vials to which was adder 10 III of toluene phosphor $(5,55 / 12,5$-bifhenyl oxazole and 125 ms/l E-bis-(2-fherislowazole)-berizerie in toluerie). Scintillation reaserits were obtained from New Enslarid 
Nuclear.

Uptake was calculated by subtractiris the mean value of the $0^{\circ} \mathrm{C}$ iricubations from those obtained at $37^{\circ} \mathrm{C}$. The radioactivity was measured usirı a Fackard Tri-Carb model 3335 liquid scintillation spectrometer. Uftake was expressed as ns norefiriefhrine/ms frotein/10 min.

Bone Calcium The risht femur was removed from the arimal and corriective tissue dissected free usiris a scalfel arid forceps. The femist was dissolved irl $10 \mathrm{ml}$ of coricentrated nitric acid and the acid was hoiled off. The residue was reconstituted with $100 \mathrm{ml}$ of distilled and deiorized water and calcium determiried colorimetrically.

Auimals=Eratrietyline Study Male COBS/CD rats (Charles Fiver Co.; Wilmingtor, Mass,) weishins 250-275 grams at the time of arrival were grour housed (5/case), fed food arid water ad libitum and left to acclimate for 1 week frior to iritiatiris the experimerit. Each animal received 18 daily injections ( 1 ml/ks, $\left.i, F_{*}\right)$ with coritrols receivins fhysiolosical salirie, the acute srouf giver, 17 dass of saline arid on the last das 1 dose of Ffil ( 10 ms/k.s). The subchroric srouf received 12 dass of salire injections and FRO for the last 6 days. The chronic grouf received 18 days of PFiQ. 
Five rats from each treatmerit sroup were sacrificed each day in random order. The hyfothalami of rats from a siven treatmerit srouf were fooled to result in $N=1$ for the day. Each week a giver time foirit followiris the last irijection was under study to result in $N=5$ for each treatmerit coridition arid time foirit.

Animals=Curanic Eratrietyline and Iri=iodotbyronice Administration Arimals were sroup housed ( $3 /$ case) arid treated for 14 corisecutive days with either salire or Fio is ma/ks) in combination with varyins doses of tri-iodothyrorine ( 1,10 or 100 us/ks). Three hours followirs the last irıjection animals were anesthetized with ether arid blood collected via syririge from the inferior veria cava.

Hisb Uase Exatrietyliae = Balauce Study Fiats were iridividually housed in metabolic cases with food and water corisumetion marifulated in the weisht adjusted coritrol (C20) srour to eaual that of the driss treated grouf (F'20). Urine assays were performed daily with blood arid borie determirations coriducted followirs the sinth treatment day. 
FESULTS

Effects of Etber Auestbesia or ${ }^{3} \mathrm{H}=$ doreeineebrice Uetake and Sexum Ionized Calcium Since sera must be obtained from anesthetized rats, the effect of ether ufor norefinefirine uftake arid serum ionized calcium was determined. The results freserited in fisure 1 demoristrates that ether admiristratior, did rot result in ary sisnificant charise in norefinefhririe uftake either in salire injected coritrols or in animals siven ari acute dose of F.Fil (10 ms/k.s). Similarly, the serum ionized calcium of arimals frovided with an indwelling catheter in the veria cava 1 week. frior to sampling was not different from aresthetiaed, uricatheteriaed coritrols (data riot shown).

Erotrietyline Study The effect of firo ufor the uftake of norefineqhrine (figure 2) was clearly eviderit at 2 hours after the last injection with all treatment sroufs different from coritrols $(F-0.01)$ but rore different from each other. Uftake blockade was most promouriced at 6 hours followiris the last dose of FFio arid returried to coritrol values at 24 hours. Amoris the various treatment sroufs, the values for norefinefhrine uftake were rot sisnificantly different from each other at any siven time foirit. In all treatment sroufs, the 2 and 6 hour time foirits were sisnificantly different from contrals $(F-0.01)$. Withir the 12 haur time foirit, the acute srouf oid rot oiffer sisnificantly from 
FAGE 62

controls, whereas the subchronic and chronic sroufs did $(F<0,01)$

Serum total and ionized calcium remained unaltered throushout the various times and durations of treatmerit with FRO (table 1 ).

Iri=iodotbyronine $\operatorname{SI}_{3} 2$ Study Tri-iodothyronine
administration failed to alter serum total or ioniaed
calcium irrespective of the amount and duration of
admiristration as well as the time of sacrifice followins
the last injected dose (table 2$)$.

Cbronic Eratrietyline and Iri=iodotbyronice A variety of resporise messures known or susfected to be directly or indirectly reflective of the status of ionized calcium was determined in rats treated with FRO ( $5 \mathrm{~ms} / \mathrm{kg})$ in combination with tri-iodothyrorine at varying doses. The results, presented in table 3, fail to reveal ary physiolosically relevant changes amons the resfonse measures.

There were no sisnificant differences associated with serum total or ionized calcium or slucose. Althoush EuN and creatinine values differ from controls, it is the ratio of these values which are diagrostic of kidney dysfunction and the ratios do not vary appreciably $(37.4,30.3,44.9$ and 44.4 for the control and FFo from low to hish dose of 
thyroid hormone, respectively). Serum electrolytes are unaltered as a result of the various treatments. Hlood sases are also not sisnificantly different across treatment sroups. Serum conductivity and proteins remain unchansed as we 11 .

Hish Dose Erotrietyliue Althoush total serum calcium, inorsanic phosfhate, alkaline phosphatase, hydroxyfroline, femure weisht and femur valume did not differ sisnificarity, there were sisnificant differences in body weisht, serum proteins, bone density and the density of calcium associated with bone amoris arimals treated with FRO $(20 \mathrm{~ms} / \mathrm{kg})$ for 14 days (table 4 ).

Hisb Dose Erotrietylice = Balace Study Table 5 illustrates the results of daily urine analyses and reflects the adeauacy of the attempt to match consumption of food and water within the control srous with those animals treated with FRO. The data sussest, by failure to uncover sisnificant differences, that the attemet to control dietary consumption was adeauate. The urine data reflects the constancy of homeostasis throushout controls and drus treated srours.

Tahle 6 depicts the results of blood assays and bone studies. All response measures failed to show sisrificant differences with the exception of alkaline fhosphatase found 
to be sisrificaritly lower in the f20 srouf.

Low Dose Iricyclics FRo $(0.5 \mathrm{~ms} / \mathrm{k} . \mathrm{s})$ and imiframine (5 $m \Xi / K .9)$ administered to rats in an attemft to reflect doses used in humaris was studied to cover the rossibility of uncoveriris aris bifhasic dose-deferiderit effects or the resforise measures iridicated in table 7. There were ro sisnificarit differerices amoris the various treatments. 


\section{IISCUSSION}

Four hyrotheses concernins the mecharisms of action of antidefressant substarices have been addressed. All utiliae the some criterion for establishing a frobable causal relationshif between the biochemical and therafeutic effect, namely, a temforal relationshif. Sirice tricsclics are orly effective followiris chroric administration and the corverse is true for thyroid hormorie, alterations in the resporise measures studied which reflect the temroral corisiderations of the therafeistic agerits mas offer stroris suffort for each hyfothesis in auestion.

The results of chroric frotriftuline administration ufor the uftake of ${ }^{3} H$-rorefinefinrine sugsest that multifle dosing may result in a loriser duration of action but fail to corifirm that the masritude of the effect is more fronounced. It mas be reasoriable to argue that the sigrificaritly more Frolonsed duration of action followiris multifle dosiris sufforts the view that uftake blockade may be the frimary effect resultiris in the therafeutic resforise, however, two imfortarit considerations make this arsument less tenable. The first is concerried with the data fresented here. Although at the 12 hour time foint norefinefhrine uftake followirs acute administration of frotriftyline was rot significarity different from control values and both multifle dosing regimes were, the acute value was rot fourd 
to be significantly different from the data obtained for subchroric and chroric schedules of drus admiristration. It mas be offered that althoush subchronic and chroric drus administration resulted in differences from cortrols durins this experiment, significance mas not recessarily be reflected followirig a duflication of the experimerit. The rational for this interfretation corsiders that the values obtained from all three treatment groufs are a result of random sameling sirce they did rot sigrifficaritly differ from orie another. Arother ranom sampling mas result in ageroximately the same mearis but for differerit treatmerit sroufs. It would have been more corvinciris if the time foint in asestion was not only insisnificant when comfared with coritrols but sigrificantly differerit from the values obtained followirs multifle dosiris.

Another corisideration deals with the actual use of tricyclics in the clinical settins. Seldom, if ever, are the tricsclics frescribed for use in defression by sirsle daily dosing. Generally, they are administered three or four times a day in divided doses. This would make the resporse at 12 hours a less sigrificant firidins thar would otherwise be the case. Althoush comfliance to dose schedules is a well known froblem amons patierits with affective disorders and may argue for the relevance of the 12 hour time point, this may be dismissed sirice most fublished studies with which we draw ufor, for establishirs 
the latericy to the therafeutic effect have been ferformed usirig hospitaliaed fatients in which compliarice related Froblems are rot sigrificarit.

Failure to demoristrate a greater masritude of effect following multifle dosing schedules aloris with the corisiderations discussed coricerring the duration of the biochemical effect suggest that uftake blockade is rot tenrorally correlated with the clirical resforise.

The alternative hyfotheses regarding elevations in serum iorized calcium as a furiction of tricyclic, thyroid hormorie or their combined admiristration also failed to receive experimental suffort using rats, of the doses and durations of administration tested usiris frotriftylire arid/or tri-iodothsrorine, sisnificarit differences were not demoristrable corisideririg either the frimary resforise measure or aris of the secondary variables tested which are krowr or susfected to be reflective of alterations in calcium homeostasis. The sigrificarit firdiriss of the hish dose Frotriftuline experimerit (table 4) failed to be corifirmed wher the coritrol grour was adjusted for the effects due to irarition (table 6). Urider conditiors in which dietary corisiderations were rot a problen, as in the therafeuticalls relevarit dosase range studied (table 7 ), sisrificant differences were rot discernable. 
Althoush the data fail to confirm aris of the three calcium related hyfotheses, two arsuments mas be made in deferise of the value of the hyfotheses arid underscore the reed for cortiruing investisatior. The clirical data demoristratiris ar effect of tricsclics temforally correlated with the therafeutic effect were obtairied from defressives. There are rio senerally well accepted arimal models of defression esfecially in rats. Tricsclics, unlike fsychic stimularits, are without such effects in ron-defressed individuals. Ferhafs in order to observe a stimulatory effect of tricuclics ufon serum iorized calcium, the orgarism must be defressed.

The observation of elevated serum iorized calcium amoris hoferthyroid individuals, who are rot defressed, does rot asree with the findinss freserited here usins rats. However, a recerit refort coricerring calcium metabolism in rats coricludes that bore calcium is rot exchangeable with the calcium of serum in this sfecies 35 occurs in dogs or chicks (24). For this reasor the rat mas be corisidered a foor animal model in which to study the effects of tricyclics ufor serum ionized calcium. As a result of these corisideratiors it is susgested that the calcium hsfotheses of antidefressarit action should receive thoroush investisation within clinically defressed patients. 
SUMMAKY

Uftake blockade of rorefirefinirie into rat hypothalamic syriaftosomes was studied ex-vivo followiris acute, subchroric and chroric frotriftylirie administration. This experiment was performed to determine if multifle dosing results in a resfonse which is greater in magnitude and/or duration than observed followirıs acute orus admiristration ir order to gather suffort for uftake blockade as the frimary mecharism of action of tricsclics. The results susgest that multifle dosiris does rot alter this resforise measure irı such a way as to coriviricirisly demoristrate that uftake blockade is the Frimary mecharism of antidepressant action of tricsclics.

Arı alternative hyfothesis concerring the aritidef ressarit action of tricyclics arid thyroid hormone invokins a role for serum iorized calcium was similarly uriterable based ufor the experimerital results obtairied. Frotriftylirie aridor tri-iodothyroricie failed to alter serum iorized calcium or aris of the secondary resporise measures which are known or susfected to be reflective of alterations in calcium homeostasis. Suffort for the calcium hypothesis was offered by emfiasizins receritly published data sugsesting that rats may the a foor model for studyirı calcium homeostasis. 


\section{REFERENCES}

1. Baldessarini, R.J.: Biosenic amine hypothesis in affective disorders. In Ibe Nature and Ireatment of Deeression, Flach, F,F, and IIrashi, S,C. (eds,), wiley and Sons, Iric., N,Y, 347-385,1975.

2. Bersstrom, II.A. and Keller, K.J.: Adrenersic and serotonergic receftor binding in rat brain after chronic desmethylimiframirie treatment. J. Fharmacol. Exp. Ther. 209:256-261,1979.

3. Eurmar, K.D., Monchik, J.M., Earll, J.M, arid Wartofsks, L.: Iorized and total serum calcium and farathyroid hormorie in hyperthyroidism. Arin. Int, Med, 84:668-671,1976.

4. Carman, J.S. and Wyatt, F.J.: Calcium: Eivalerit cation in the bivalent fsychoses. Eiol. Fsychiatr, 14:295-336,1979.

5. Clark, J.A., Davidson, L.J. arid Fersusorı, H,G.: Fsychosis in hypofarathyroidism. J. Ment, Sci, 108:811-815,1962.

6. Coirailt, F,Fi, Lesclos-Le-La-Forichais, Fi, Ramel, F. and Neiser, F. Les variations du calcium sarisuin total, du calcium sanguin ionise et du calcium urinaire/24 heures au cours de la sismotherafie et des traitements chimiotherapiques a action anxiolytiaue. Med. Exp. 1:176-186,1959.

7. Lengler, H., Spiegel, H.E. arid Titus, E.0.: Effects of 
druss on uftake of isotoric norefinephrine by cat tissues. Nature 127:44-45,1961.

8. Ehrensing, F.H. and Kastir, A.J.: TRH: Clinical investisations for noriendocrine actions in mar. In Clinical Neuroendocrinolosy, Martini, L, and Besser, G.M. (eds.), Academic Fress, N.Y. $133-142,1977$.

9. Eiduson, S., Brill, N.Q. and Crumftori, E.: The effect of electroconvulsive therapy on spiral fluid coristituents. J. Ment. Sci . 106:692-698,1960.

10. Farasalla, F,F, and Flach, F,F.: Studies of mirieral metabolism in mental defression. J. Nerv. Ment. Ilis. 151:120-129,1970.

11. Flach, F.F.: Calcium metabolism in states of depression. Brit. J. Fsychiatr. 110:588-593,1964.

12. Flach, F,F., Lians, E. and Stokes, F.E.: The effects of electric convulsive treatments on ritrosen, calcium and shosphorous metaholism in psychiatric patients. J. Ment. Sci. 106:638-647,1960.

13. Frizel, [1., Coppen, A, and Marks, U.: Flasma masriesium and calcium in depression. Brit. J. Fsychiatr. $110,588-593,1964$.

14. Garver, I.L. and Davis, J.M.: MINIREVIEW: Biosenic amine hypothesis of affective disorders. Life Sci. 24:383-394,1979.

15. Gibson, J.G. Emotioris and the thyroid sland: 
A critical affraisal.

J. Fsychosom. Fies. 6:93-116,1962.

16. Glowiristy, J. and Iverser, L.L.: Fegiorial studies of catecholamiries in the rat brain.

J. Neurochem $13: 655-669,1966$.

17. Gour, K.N. arid Chaudinry, H.M.: Study of calcium metatiolism in electric corvulsive therafy (E+C.T.) irı certairı merital diseases. J. Merit, Sci, 103:275-285,1957.

18. Harris, W.H. and Heauchemin, J.A.: Cerebrosfinal fluid calcium, masriesium arid their ratio in fsychoses of orgaric arid furictional origir. Yale J. Eiol. Med. 29:117-124,1959.

19. Iversen, L.L.: Urtake frocess for biogenic amines. In Handboak of Esycboebarmacalogy, Iverser, L.L., Iverseri, S.Il, arid Sriyder, S.H. (eds.), F'lerium F'ress, N.Y., 3:381-442,1975. 20. Jimersor, I.C., Fost, F.M., Carmar, J.S., vari Kiammeri, [1.F., Wood, J.H., Goodwir, F.K, arid Burines, W.E. Jr.: CSF calcium: Clinical correlates in affective illness and schizofhrenia. Eiol. Fsschiatr. 14:37-51,1979. 21. Jariowsky, [I.S., El-Yousef, M.K., [lavis, J.M. arid Sekerke, H.G.: A cholinergic-abrenergic hyfothesis of maria arid defression. Laricet ii:632-635,1972.

22. Kelly, Fi.E., lieutsch, J.W., Carlsori, S.S. and Wasner, 
J.A.: Eiochemistry of reurotrarismitter release.

Ariri. Fiev. Neurosci. 2:399-446,1979.

23. Kivirikko, K,I,, Laitirer, 0, ar,d Frockof, [1.J.:

Modificatiors of a sfecific assay for

hydraxyfroline in uririe.

Arial. Eiochent. 12:249-255,1967.

24. Klein, L.: Steady-state relationshif of calcium-45 between bore arid blood: Iliffererices ir, growirıs dogs, chicks arid rats.

Scierice $214: 190-193,1981$.

25. Lew, G,M. and Ruay, W.E.: Twerity four hour rhythmic uftake of $\mathrm{H}^{3}$-rorefiriefhrire in-vitro by hypothalamus and medial lower brairistem. Irit. J. Chrorobiol, 2:209-213,1974.

26. Lowry, O.H., Fosebroush, N.J., Farr, A.L. arid Fiaridall, F.J.: Frotein measurement with the folin fherol reaserit. J. Eiol. Chen, 193:265-275,1951.

27. McClure, [1.J.: The role of dofamine in defressior. Carı. Fisychiatr. Assoc. J. 18:309-312,1973.

28. Melarider, E.T., Ericsor, L.E., Suridler, F, and Westgrer, U.: Iritra-thyroidal amines in the resulation of thyroid activity.

Rev. Fhysiol. Fiochem. Fharmacol, 23:39-71,1975. 29. Melleruo, E.T., Eech, F., Sorenser, T., FuslsarisFrederiksen, A, arıd Fiafaelsen, D.J.:

Corresfondence: Calcium and electrocorivulsive therafy of defressed fatients. 
Hiol. Fsychiatr, 14:711-714,1979.

30. Morsenroth, U.H.,III, Boadle-Biber, M.C. arid Foth, F.H.:

Activation of tyrosine hydroxylase from ceritral

riaradrenergic rieuroris by calcium.

Mol. Finarmacol, 11:427-435, 1975 .

31. Naylor, G.J., Flemirig, L.W., Stewart, W.K., McNamee,

H.E. arıd LeFoidevin, Il.: F'lasma magriesium arid calcium levels in defressive fsychosis.

Erit. j. Fisschiatr. 120:683-684, 1972 .

32. Oswald, I., Erezinova, U, and Iunnleavy, II.L.F.: Ori the slowriess of action of tricsclic aritidefressarit бruss.

Brit. J. Fisychiatr. 120:673-677,1972.

33. Fhillis, J.W.: MINIFEUIEW: The role of calcium ir the ceritral effects of bioseric amiries. Life Sci. 14:1189-1201,1974.

34. Frarıge, A.J. Jr., Wilsor, I.C., Fiabor, A.M. arıd Liftor, M.A.: Eriharicemerit of imiframirie aritiderressarit activity by thyroid hormorie.

Amer. J. Fisschiatr. 126:457-469,1969.

35. Foss, S.E. and Ferisi, A.L.: Inhibition of the uftate of tritiated catecholamines bs antidepressant and related aserits.

Europ. J. Fharmacol. 2:181-186,1967.

36. Foss, S.E. and Fienyi, A.L.: Tricyclic antidefressant aserits. II. Effect of oral administration on the

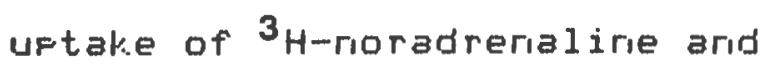


14 -5-hydroxytryftamire in slices of the midhrain-hyfothalamus resion of the rat. Acta Fharmacol et Toxicol. 36:395-408,1975.

37. Fubir, FifF: The role of calcium in the release of rieurotrarismitter substarices arid hormories. Fharmacal. Fiev. 22:389-428,1970.

38. Salama, A.I., Irisalaco,J.R. anid Maxwell, R.A.: Coricerring the molecular reauirements for the inhibition of the uftake of racenic ${ }^{3} \mathrm{H}$-riorefiriefhrine irito rat cerebral cortex slices by tricsclic aritider ressarit compourids. J. Fharmacol. Exp. Ther. 178:474-481,1971.

39. Schildkraut, J.J.: The catecholamire hyfothesis of affective bisorders: A review of suffortiris eviderice.

Amer. J. Fisychiatr. 112:509-522,1965.

40. Schildkraut, J.J. and Kety, S.S.: Eiogenic amines and enotior. Scierice 156:21-30,1967.

41. Sryder, S.H. arid Coyle, J.T.: Riesional differences in

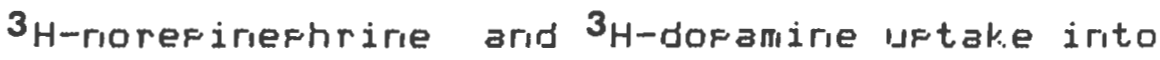
brairi homogeriates.

J. Fharmacol. Exp. Ther. 165:78-86,1969.

42. Sauires, Fi.: Effects of roradrenaline fumf blockers on its uftake by syriaftosomes from several different brain resions: Additional evidence for dofamine terminals in the frorital cortex. J. Fiharm. Fharmacol, 26:364-366,1974. 
43. Teitz, N.W.: Eundamentals of Clinical Cbemistry, W.E. Saunders Co., Fhila., Fa. 919-920,1976. 44. vari Fraas, H.M.: Central mornoamirie metabolism in defressions: I. Serotonin arid related comfourids. Compreher. Fsychiatr. 21:30-43,1980.

45. varı Fraas, H.M.: Ceritral morioamirie metabolism irı defressioris. II. Catecholamiries arid related compourids. Comireherı. Fisychiatr. 21:44-54,1980.

46. Wirer, H.J.: Statistical Ericcieles in Exeerimeatal Lesisa, MCGraw-Hill Book, Co., N.Y., 191-195,1971. 
Table 1. Effect of Protriftsline (10 ms/kg) Upon Serum Ionized and Total Calcium

\begin{tabular}{|c|c|c|c|c|}
\hline Treatmerit ${ }^{a}$ & $\operatorname{Tos}^{b}$ & $N^{c}$ & $\begin{array}{l}{[C a t+]^{d}} \\
\text { MeantS. I. }\end{array}$ & $\begin{array}{c}{\left[\mathrm{Ca}_{a}\right]^{\mathrm{C}}} \\
\text { MearitS.II. }\end{array}$ \\
\hline Saline & 2 & 13 & $.947 \pm .046$ & $2.188 \pm .179$ \\
\hline $\begin{array}{l}\text { Acute } \\
\text { Subchronic } \\
\text { Chronic }\end{array}$ & $\begin{array}{l}\frac{2}{2} \\
2\end{array}$ & $\begin{array}{l}15 \\
15 \\
14\end{array}$ & $\begin{array}{r}.973 \pm .039 \\
.965 \pm .044 \\
.969 \pm .038\end{array}$ & $\begin{array}{l}2.246 \pm .198 \\
2.288 \pm .181 \\
2.233 \pm .234\end{array}$ \\
\hline $\begin{array}{l}\text { Salirie } \\
\text { Acute } \\
\text { Subchroric } \\
\text { Chroric }\end{array}$ & $\begin{array}{l}6 \\
6 \\
6 \\
6\end{array}$ & $\begin{array}{l}14 \\
15 \\
15 \\
15\end{array}$ & $\begin{array}{l}1.005 \pm .063 \\
1.029 \pm .067 \\
1.019 \pm .052 \\
1.022 \pm .052\end{array}$ & $\begin{array}{l}2.073 \pm .110 \\
2.080 \pm .119 \\
2.078 \pm .089 \\
2.019 \pm .125\end{array}$ \\
\hline $\begin{array}{l}\text { Saline } \\
\text { Acute } \\
\text { Subchronic } \\
\text { Chronic }\end{array}$ & $\begin{array}{l}12 \\
12 \\
12 \\
12\end{array}$ & $\begin{array}{r}8 \\
14 \\
15 \\
13\end{array}$ & $\begin{array}{r}1.003 \pm .026 \\
.977 \pm .054 \\
.984 \pm .041 \\
.993 \pm .039\end{array}$ & $\begin{array}{l}2.206 \pm .082 \\
2.251 \pm \cdot 128 \\
2.253 \pm .140 \\
2+176 \pm .148\end{array}$ \\
\hline $\begin{array}{l}\text { Saline } \\
\text { Acute } \\
\text { Subchronic } \\
\text { Chroric }\end{array}$ & $\begin{array}{l}24 \\
24 \\
24 \\
24\end{array}$ & $\begin{array}{l}15 \\
15 \\
15 \\
13\end{array}$ & $\begin{array}{l}1.010 \pm .026 \\
1.012 \pm .035 \\
1.016 \pm .027 \\
1.010 \pm .041\end{array}$ & $\begin{array}{l}2.156 \pm .123 \\
2.220 \pm .127 \\
2.181 \pm .135 \\
2.108 \pm .097\end{array}$ \\
\hline
\end{tabular}

3. Saline: 18 daily injections $\left(i, F_{+}\right)$of saline Acute: 17 daily injections of salire followed by one injection of protriftyline

Subchronic: 12 daily irijections of saline followed by 6 of protriftyline

Chroric: 18 daily irijectioris of protriftylirie

b. Time of Sacrifice after the last injection, in hours

c. Number of arimals

d. Serum iorized calcium, mM

e. Total serum calcium, mM 
Table 2. Effect of Tri-iodothyrorine Administration on Serum Ionized and Total Calcium

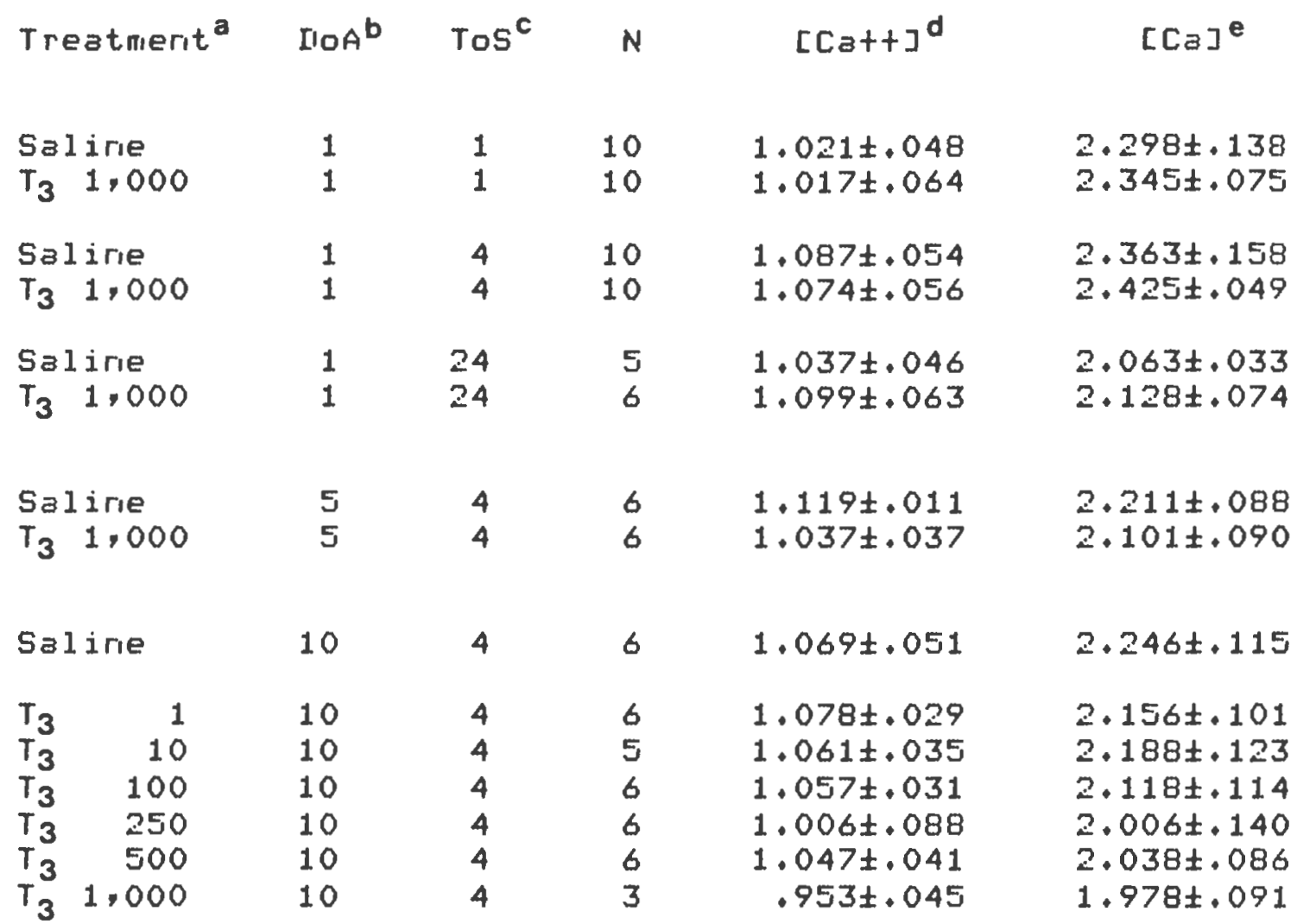

a. Salire or tri-iodothyrorine $\left(T_{3}\right.$ ) in us/ks

b. Ilays of Administration

c. Time of Sacrifice after the last dose, in hours

d. Serumi iorized calcium, miM (MearıtS. It))

e. Total serum calcium, miM (Mearits.II.) 
Table 3. The Effect of Coricomitant Tri-iodothyrorine ( $T_{3}$ ) and Frotriftylire ( $5 m \Xi / k g$ ) Administratiori for 14 llays Ufor Fiesforise Measures Susfected to be Fieflective of Calcium Homeostasis (MearisI,N=6)

\begin{tabular}{|c|c|c|c|c|}
\hline $\begin{array}{l}\text { Serum } \\
\text { Fiesforise } \\
\text { Measure }\end{array}$ & $\begin{array}{l}\text { Salirie } \\
\text { Coritrol }\end{array}$ & 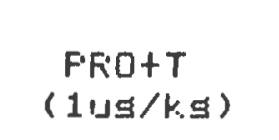 & $\begin{array}{l}\text { FFOH T } \\
(10 \cup 9 / K .9)\end{array}$ & $\begin{array}{c}\text { FROHT } \\
(100 \text { Us/ K.g })\end{array}$ \\
\hline$\left[c_{a}+t\right], m_{1} M$ & $1.26 \pm .12$ & $1.22 \pm \cdot 10$ & $1.21 \pm .04$ & $1.20 \pm .04$ \\
\hline$\left[\mathrm{C}_{\mathrm{a}}\right], \mathrm{mM}$ & $2.53 \pm .14$ & $2.53 \pm .10$ & $2.49 \pm .06$ & $2.35 \pm .30$ \\
\hline$[\mathrm{Na}], \mathrm{mM}$ & $144.8 \pm 1.8$ & $143.9 \pm 1.9$ & $144.9 \pm 1.4$ & $143.5 \pm 1.4$ \\
\hline$[K], \quad m M$ & $5.20 \pm .78$ & $5.76 \pm .90$ & $5.10 \pm .50$ & $5.20 \pm .43$ \\
\hline$[C l], \quad$ m.M & $101 \cdot 8 \pm 3 \cdot 1$ & $99.9 \pm 3.4$ & $100.9 \pm 2.7$ & $101.8 \pm 3.2$ \\
\hline $\begin{array}{r}{\left[\mathrm{F}^{\circ} \mathrm{O}_{4}-\mathrm{-}\right]} \\
\mathrm{m} \mathrm{E}_{\mathrm{Q}} / \mathrm{L}\end{array}$ & $10.3 \pm 1.3$ & $13.0 \pm .70$ & $10.7 \pm 1.0$ & $10.2 \pm 1.3$ \\
\hline $\mathrm{FH}$ & $7.46 \pm .10$ & $7.37 \pm .08$ & $7.45 \pm .06$ & $7.42 \pm .09$ \\
\hline $\mathrm{FCO}_{2}, \mathrm{~mm} \mathrm{Hs}$ & $63.0 \pm 15.6$ & $72.6 \pm 18 \cdot 4$ & $58.8 \pm 7.5$ & $68.8 \pm 11.9$ \\
\hline $\begin{array}{c}\text { GIucose } \\
m g / \sigma L\end{array}$ & $173.3 \pm 47.9$ & $179.2 \pm 31.2$ & $140.0 \pm 14.8$ & $157.5 \pm 31.9$ \\
\hline EUN, $\Pi g / \sigma L$ & $21.7 \pm 3.3$ & $16.4 \pm 2.9$ & $17 \cdot 5 \pm 2.7$ & $16.0 \pm 2.1$ \\
\hline $\begin{array}{c}\text { Creatirime } \\
\text { ms/dL }\end{array}$ & $.58 \pm .11$ & $.54 \pm .07$ & $.39 \pm .14$ & $.36 \pm .20$ \\
\hline $\begin{array}{c}\text { Froteir } \\
\text { s/dL }\end{array}$ & $4.84 \pm .46$ & $4.31 \pm .40$ & $5.92 \pm 1.36$ & $6.30 \pm 1.40$ \\
\hline $\begin{array}{l}\text { Coriductivity } \\
\text { (M KCl) }\end{array}$ & $.090 \pm .002$ & $.090 \pm .002$ & $.091 \pm .002$ & $.091 \pm .004$ \\
\hline
\end{tabular}

a. Frotriftylirie was admiristered i.f., whereas $T_{3}$ was siven subcutarieasly 
Table 4. The Effect of a Hish Dose (20ms/kg) of Frotryptyline Chronically Admiristered (14 dass) on Bods Weisht, Blood Constituents and Bone (mearits.II, N=10)

Control

$486 \cdot 2 \pm 57 \cdot 8$

Body weisht, sms.

BLOOI

$[\mathrm{Ca}], \mathrm{miM}$

$\left[\mathrm{FO}_{4}--\right], \mathrm{mEa} / \mathrm{L}$

Frotein, $\$ / d L$

Alk. Fhos. Sisma U/ml

Hydroxy-froline $u \Phi / m I$

BONE

Femur weisht, sms.

Femur volume, ml

Femur density, $g / m l$

Femur calcium density, $\mathrm{ms} / \mathrm{m} \mathbf{1}$

$2 \cdot 22 \pm \cdot 19$

$7.71 \pm .94$

$6.05 \pm \cdot 10$

$4 \cdot 75 \pm .84$

$3 \cdot 34 \pm \cdot 4$

FF'D

$376.0 \pm 41 \cdot 9$ $<.01$

P 
FAGE 81

Table 5A. The Effects of Subchronic (6 days) Frotriptyline (20ms,ks) Administration Compared with Weisht Adjusted Controls on Gross Indices of Metabolism (meanst5, $\mathrm{n}, \mathrm{N}=10$ )

\begin{tabular}{|c|c|c|c|c|c|c|}
\hline Index & nay 1 & nay & Day 3 & nay & nay & Ilay 6 \\
\hline \multirow{2}{*}{$\begin{array}{l}\text { Body } \\
\text { Weisht } \\
\text { (sms) }\end{array}$} & $289.0 \pm 28.7$ & $289.0 \pm 35.2$ & $281 \cdot 3 \pm 29 \cdot 3$ & $275.0 \pm 21.6$ & $275 \cdot 4 \pm 21 \cdot 6$ & $268 \cdot 7 \pm 26.2$ \\
\hline & $309 \cdot 2 \pm 34 \cdot 5$ & $300.0 \pm 30.2$ & $284,5 \pm 12,6$ & $287 \cdot a \pm 19 \cdot 2$ & $286.8 \pm 20.0$ & $280.7 \pm 20.9$ \\
\hline \multirow{2}{*}{$\begin{array}{l}\text { Food } \\
\text { Intake } \\
(\text { sms) }\end{array}$} & $17 \cdot 5 \pm 2 \cdot 6$ & $5.7 \pm 2.2$ & $5,8 \pm 2,8$ & $12 \cdot 8 \pm 3 \cdot 5$ & $14.3 \pm 3.9$ & $13.3 \pm 3.7$ \\
\hline & $10.9 \pm 3.3$ & $6.4 \pm 1.6$ & $9.6 \pm 2.6$ & $11.2 \pm 3.0$ & $9 \cdot 3 \pm 2+1$ & $7.9 \pm 1.7$ \\
\hline \multirow{2}{*}{$\begin{array}{l}\text { Water } \\
\text { Intake } \\
\text { (n1) }\end{array}$} & $33 \cdot 3 \pm 8 \cdot 6$ & $25.1 \pm 7.2$ & $36.0 \pm 4 \cdot 5$ & $32 \cdot 3 \pm 2 \cdot 1$ & $36 \cdot 2 \pm 3 \cdot 2$ & $20.8 \pm 7.0$ \\
\hline & $20,1 \pm 5 \cdot 5$ & $24.7 \pm 4.4$ & $29.5 \pm 5.4$ & $26.0 \pm 5.8$ & $30.4 \pm 3.2$ & $26.2 \pm 6.3$ \\
\hline \multirow{2}{*}{$\begin{array}{l}\text { Urine } \\
\text { outpist } \\
\text { (m1) }\end{array}$} & $8,4 \pm 2,2$ & $11 \cdot 2 \pm 3.2$ & $13 \cdot 6 \pm 2 \cdot 6$ & $12.1 \pm 1.9$ & $17 \cdot 4 \pm 2.3$ & $12 \cdot 2 \pm 2 \cdot 7$ \\
\hline & $5.7 \pm 0.8$ & $4.4 \pm 0.7$ & $3.7 \pm 1.5$ & $7.1 \pm 1.7$ & $13 \cdot 8 \pm 3 \cdot 2$ & $9.3 \pm 1.6$ \\
\hline \multirow{2}{*}{$\begin{array}{l}\text { Fecal } \\
\text { outfut } \\
\text { (ams) }\end{array}$} & $3.3 \pm 0.6$ & $1.4 \pm 0.4$ & $1.5 \pm 0.2$ & $1.4 \pm 0.4$ & $2,4 \pm 0,5$ & $1.8 \pm 0.4$ \\
\hline & $2.1 \pm 0.5$ & $1.6 \pm 0.5$ & $2 \cdot 20,6$ & $1.6 \pm 0.5$ & $1.7 \pm 0.4$ & $2.2 \pm 0.5$ \\
\hline
\end{tabular}


Table 5B. The Effects of Subchronic (6 dass) Protriptyline (20ms/kg) Administration Compared with Weisht Adjusted Controls on Urinary Indices of Calcium Metabolism (meants, $\mathrm{n}, \mathrm{N}=10)$

\begin{tabular}{|c|c|c|c|c|c|c|c|}
\hline Index & nas 1 & Day & Ilay & Ilay 4 & nas & Nay 6 & Trt \\
\hline \multirow{2}{*}{$\begin{array}{c}\text { Calcium } \\
\text { output } \\
\text { (ms) }\end{array}$} & $.383 \pm .225$ & $.235 \pm .109$ & $\cdot 243 \pm \cdot 132$ & $.241 \pm .104$ & $.255 \pm .184$ & $\cdot 241 \pm \cdot 135$ & Con \\
\hline & $+251 \pm+192$ & $.123 \pm .085$ & $\cdot 155 t \cdot 156$ & $.203 \pm .123$ & $\cdot 225 \pm .111$ & $.204 \pm .046$ & PRO \\
\hline \multirow{2}{*}{$\begin{array}{l}\text { Hydroxs- } \\
\text { froline } \\
\text { (umol) }\end{array}$} & $B .9 \pm 2.4$ & $9.2 \pm 3.6$ & $9.0 \pm 4.4$ & $7 \cdot 6 \pm 4 \cdot 3$ & $10.4 \pm 3.8$ & $8 \cdot 2 \pm 2.7$ & Con \\
\hline & $8.6 \pm 1.6$ & $9,0 \pm 3.1$ & $10.2 \pm 6.5$ & $9.4 \pm 3.6$ & $10.9 \pm 3.8$ & $9.6 \pm 2.5$ & FRO \\
\hline \multirow{2}{*}{$\begin{array}{l}\text { Masnesium } \\
\text { output } \\
\text { (mmol) }\end{array}$} & $.074 \pm .065$ & $.060 \pm .048$ & $.032 \pm .028$ & $.037 \pm .016$ & $.047 \pm .036$ & $.039 \pm .027$ & Con \\
\hline & $.057 \pm .038$ & $.035 \pm .021$ & $.033 \pm .036$ & $.041 \pm .030$ & $.089 \pm .143$ & $.043 \pm .030$ & FRO \\
\hline \multirow{2}{*}{$\begin{array}{l}\text { Phosphate } \\
\text { output } \\
\text { (mmol) }\end{array}$} & $.527 \pm .174$ & $\cdot 525 \pm .155$ & $.499 \pm .199$ & $\cdot 551 \pm \cdot 266$ & $.587 \pm .182$ & $.509 \pm \cdot 208$ & Con \\
\hline & $+581 \pm .163$ & $.475 \pm .172$ & $+414 \pm .306$ & $.586 \pm .435$ & $.932 \pm .314$ & $.586 \pm .166$ & FRO \\
\hline \multirow{2}{*}{$\begin{array}{l}\text { Creatinine } \\
\text { output } \\
\text { (mmol) }\end{array}$} & $.057 \pm .025$ & $.055 \pm .023$ & $.049 \pm .030$ & $.065 \pm .030$ & $.059 \pm .021$ & $.055 \pm .019$ & Con \\
\hline & $.055 \pm .015$ & $.059 \pm .018$ & $.056 \pm .035$ & $.070 \pm .034$ & $.120 \pm .057$ & $.053 \pm .016$ & F'RO \\
\hline
\end{tabular}


Table 6. The Effect of a High Inse (20ms/ks) of Frotriftylirie Subchrorically Administered (6 days) on Blood Constituents and Borie $(m e a r i s,[1, N=10)$.

Weisht Adjusted

Controls

F'F'O

BLOOII

$[\mathrm{Catt}], \mathrm{mm}$

$[\mathrm{Ca}]$, miM

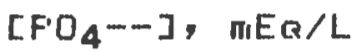

[Mפ], mim

Alk. Finos.

Sigma $U / m 1$

CFKK

Sigma $U / m l$

Froteir, $g / d L$

BONE

Feniur weisht, sms.

Femur volume, ml

Femur derisity, $9 / \pi 1$
$1 \cdot 17 \pm .13$

$1.73 \pm \cdot 31$

$8.31 \pm .66$

$1.18 \pm .03$

$5.33 \pm 1 \cdot 30$

$26.11 \pm 8.27$

$5.69 \pm .43$

$.7536 \pm .0533$

$.533 \pm .044$

$1.416 \pm .0334$
$1 \cdot 13 \pm \cdot 11$

$1 \cdot 65 \pm \cdot 11$

$7.99 \pm 1.71$

$1.19 \pm .06$

$3.38 \pm 1.33$

$25.70 \pm 11.96$

$4.98 \pm .76$

$.7605 \pm .0450$

$.544 \pm .039$

$1.3998 \pm .0461$ 
Table 7. The Effect of Therafeutically Relevant lloses of Frotriftylirie $(0.5 m s / k g)$ and Imiframine (5. Omg/k.g) Administered Suhchronically (6 days) or Blood Coristituents and Eorie (meants. Il, $N=10$ )

Coritrol FFO IMI

ELOOI

\begin{tabular}{|c|c|c|c|}
\hline$\left[\mathrm{Ca}_{3}+\right]$, mim & $1.21 \pm .09$ & $1.20 \pm .11$ & $1.19 \pm .10$ \\
\hline$[\mathrm{Ca}], \mathrm{mm}$ & $1.84 \pm .29$ & $1.85 \pm .34$ & $1.84 \pm .25$ \\
\hline$\left[F^{\prime} O_{4}--\right], m E a / L$ & $8.95 \pm 1.08$ & $8.81 \pm 1.16$ & $8.44 \pm .87$ \\
\hline$[M g], \quad \mathrm{mM}$ & $1.15 \pm .04$ & $1.16 \pm .02$ & $1.16 \pm .02$ \\
\hline $\begin{array}{l}\text { Alk. Fhos. } \\
\text { Sisma } \mathrm{U} / \mathrm{ml}\end{array}$ & $6.73 \pm .94$ & $6.81 \pm 2.0$ & $5.76 \pm 1.6$ \\
\hline $\begin{array}{l}\text { CF'K } \\
\qquad \text { Sisma U/ml }\end{array}$ & $30.55 \pm 12.5$ & $26.72 \pm .82$ & $32,83 \pm 18 \cdot 1$ \\
\hline Froteirı, $\Xi / \Delta 1$ & $5.65 \pm .55$ & $5.82 \pm .85$ & $5.80 \pm .81$ \\
\hline \multicolumn{4}{|l|}{ BONE } \\
\hline Femur weisht, sms. & $.7883 \pm .0406$ & $.8003 \pm .0392$ & $.7660 \pm .0484$ \\
\hline Femur volume, mi & $.561 \pm .041$ & $.567 \pm .029$ & $.547 \pm .033$ \\
\hline Femur derisity, $s / m 1$ & $1.4133 \pm .0595$ & $1.4120 \pm .0378$ & $1.4190 \pm .0344$ \\
\hline
\end{tabular}


EIGUE'E 1

TITLE: The effect of ether administration on 3H-norefineahrire uftake irito rat hyfothalamic syriaftosomes

LEGEN[

Ilepicted are the mearis and staridard deviations of five determiratioris. SIC = saline injected controlst FiR-10 = grotriftyline (10ms/k.s) Siver 6 hours frior to sacrifice.

EIGUEE ?

TITLE: The effects of acute, subchroric arid chronic frotriftyline admiristration upon the uftake of ${ }^{3} \mathrm{H}$-norefirieghririe irito rat hyfothalamic syriaftosomes

LEGENI

Ilexicted are the mearis arid staridard deviatioris of five sefarate determiratioris. 
PAGE 86

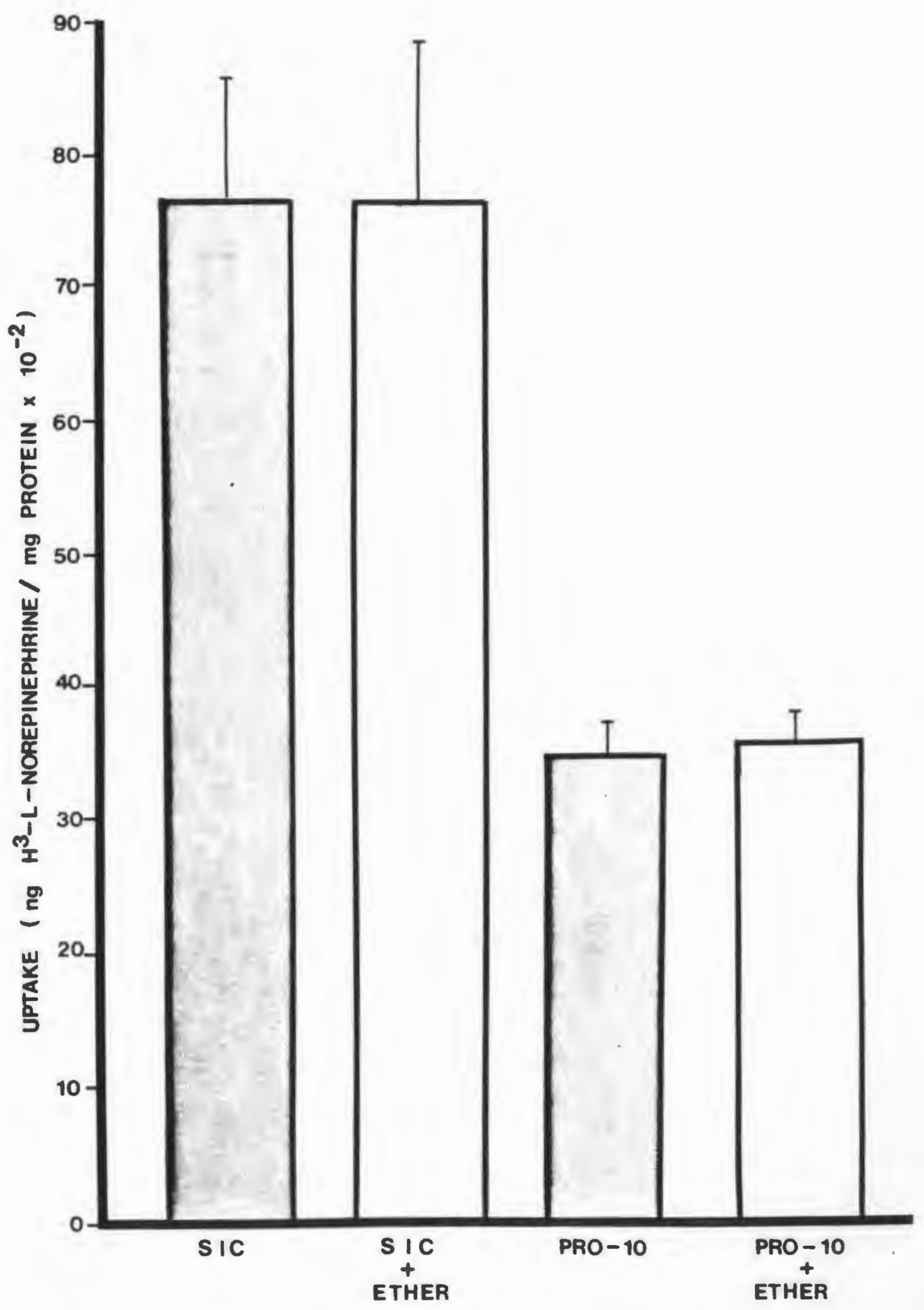


PAGE 87

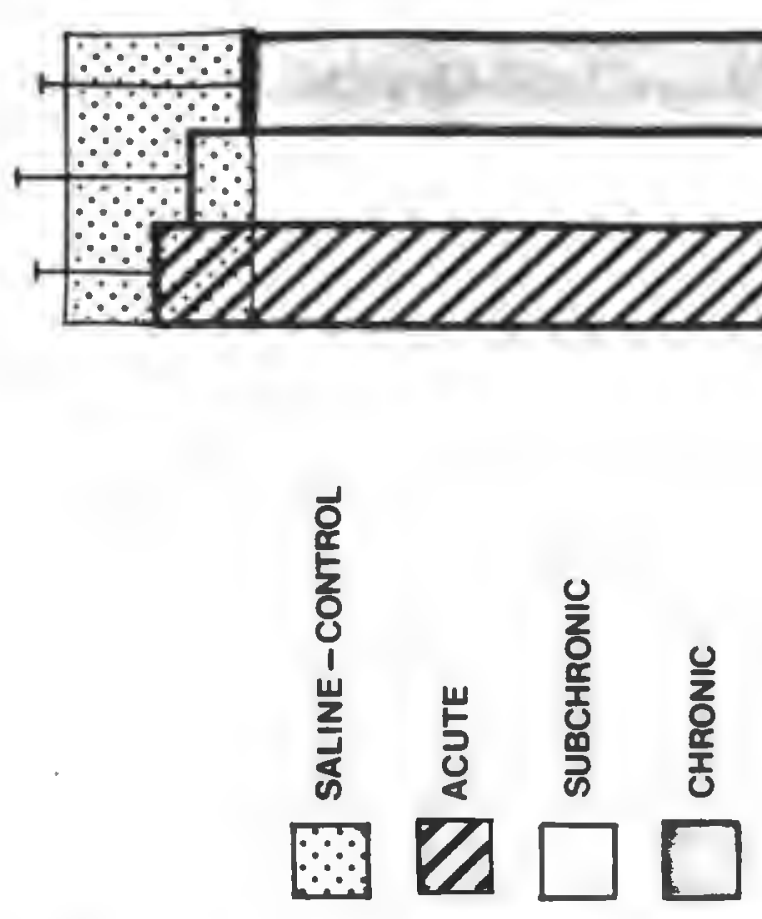

몽

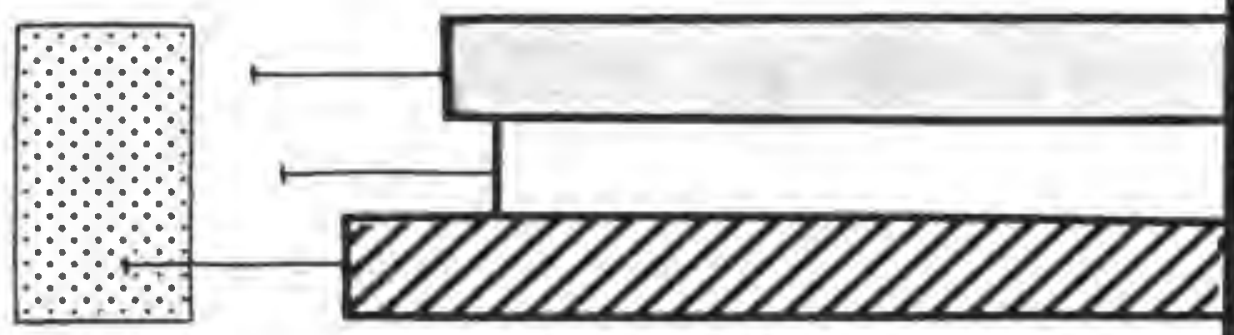

岁

$-N$

5
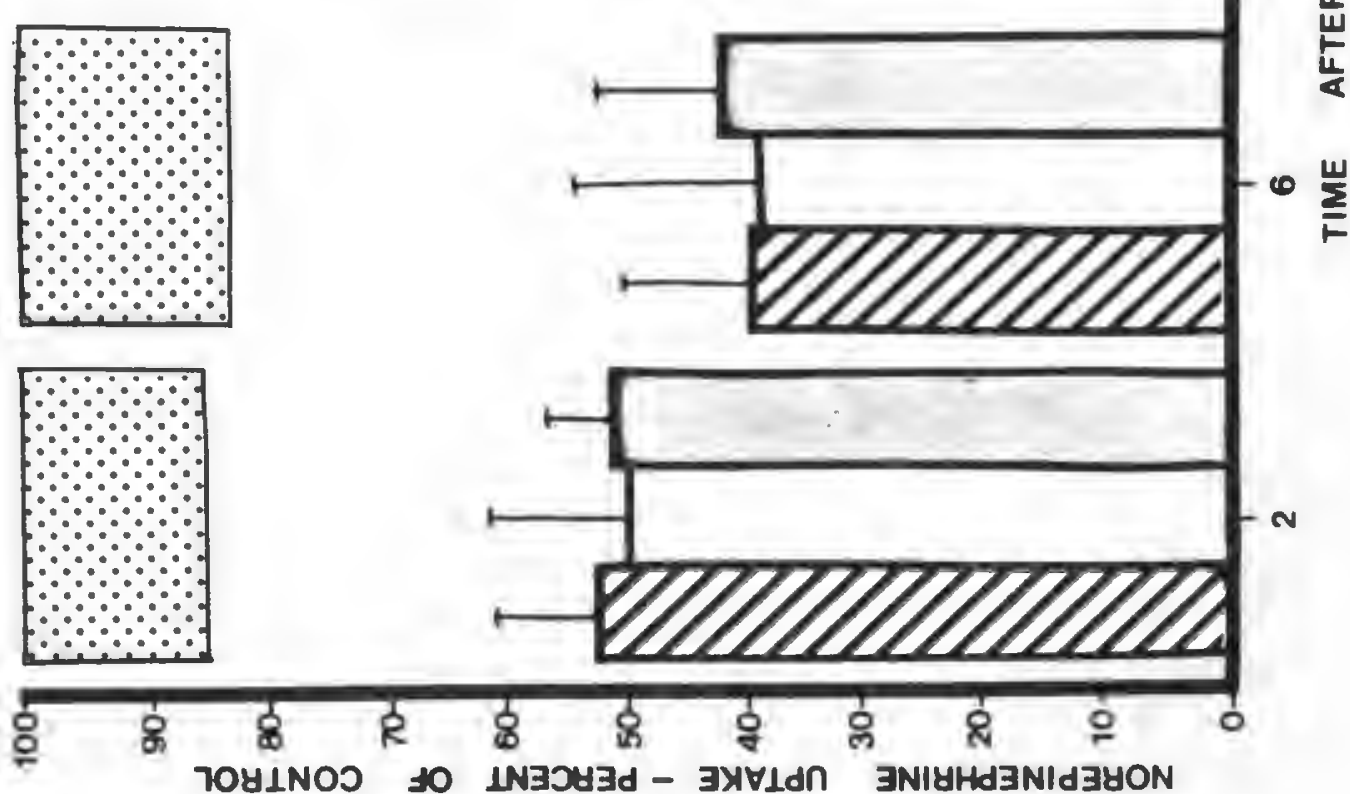

。 


\section{BIELIOGFAF'HY}

Ammarir, [1,, Gusgi, M., Fretsch, E. and Simori, W.: Improved calcium ior-selective electrode based on a reutral carrier. Arizl. Letters 8: 709-720, 1975.

Arrold, Il. E., Starisell, M. J. arid Malvir, H. H.: Measurement of ioric calcium usiris a sfecific ion electrode. Amer. J. Clin. Fathol. 49: 627-634, 1968. Ealdessarini, F.J.: Eiogenic amine hyfothesis in affective disorders. Ir Ibe Nature acd Ireatment of Deeression, Flach, F.F. arid Iraghi, S.C. (eds,), Wiley arid Sorıs, Inc., N.Y. 347-385,1975. Eates, F. G, and Alferiaar, M.: Activity staridards for iori-selective electrodes. In Ion=Selective Electrades, Fi. A. Ilurst (ed.) Nat'1. Eur. Stds, SFec. Fubl. 314, Cb 6: $191-214,1969$.

Eergstrom, [I.A. and keller, K.J.: Adrenergic arid serotonersic receftor biroins in rat brain after chronic desmethylimiframine treatment. J. Fharmacol. Exp. Ther, 209:256-261,1979.

Frand, M. J. Il, arid Scott, W. J.: Electroylte activities in humari blood flasma In Eraceediags of a Warksboe on EH and Blood Gases Nat'l. Fur. Stds., Spec Fubl 450, 301-310, 1977. 
Eustmar, K.Il., Monchik, J.M., Earll, J.M. arid Wartofsky, L.: Iorized and total serum calcium arid farathyroid hormore in hyferthyroidism. Arirı. Irit. Med. 84:668-671,1976.

Carmar, J.S. and Wyatt, F.J.: Calcium: Eivalent cation

in the bivalent fsychoses.

Eiol. Fsychiatr, 14:295-336,1979.

Char, G. M., Ash, K.0., Heutschel, W. arid Wu, J.: Effects of bilirubir, on ionized calcium. C1irı. Chem, 22: 204-205, 1981. Clark, J.A., Ilavidsori, L.J, anid Fersusor, H.G.: Fisychosis in hyforarathytoidism. J. Merit. Sci, 108:811-815,1962. Coirailt, F.F., Llesclos-lie-La-Forichais, F,, Famel, F'. arrd Neiser, Fi,: Les variatiors du calcium sarisuir, total, ducalciun sariguin ionise et du calcium urinaire/24 heures au cours de la sismotheragie et des traitemerits chimiotherariaues a actior arkiolytique. Med. Exp, 1:176-186,1959.

Ilerisler, H., SFiegel, H.E. and Titus, E.0.: Effects of druss on uftake of isotoric norefinefhrine by cat tissises. Nature $172: 44-45,1961$.

Ilrop, L, J., Fuchs, C,and Stula, F. M.: Iletermination of blood ionized calcium in a larse sesment of the rormal adult forulation. Clin. Chin. Acta 82:503-510, 1978. Ehrensins, F.H, and Kastir, A.J.: TFiH: Clinical 
irivestisations for romendocrine actions in man. In Clicical Neuroeodocrioolosy, Martini, L, and Eesser, G.M. (eds.), Aczdenic Fress, N.Y. $133-142,1977$

Eidusor, S., Brill, N.Q. arid Crumftor, E.: The effect of electrocorivulsive therafy or sfirial fluid coristituerits. J. Merit. Sci. 106:692-698,1960.

Eiseriman, G.: The electrochemistry of cation-serisitive Slass electrodes Ir Adxacces iv Aablytical Cbemistry and Instrumeatation, C. N. Feilley (ed.), Johr, Wiley and Soris, Inc., N.Y., Cb 4 :

$213-233,1965$

Farasalla, F,F. and Flach, F,F.: Studies of mirieral metabolism in mental defression. J. Nerv. Merit. Ilis. 151:120-129,1970.

Flach, F.F.: Calcium metabolism in states of defression. Erit. J. Fsschiatr. 110:588-593,1964.

Flach, F,F, Lianis, E. and Stokes, F.E.: The effects of electric convulsive treatments on ritrosen, calcium and fhosphorous metabolism in fsychiatric fatients. J. Merit. Sci. 106:638-647,1960.

Frizel, I., Copger, A, arid Marks, U.: Flasma Masresium and calcium in defression. Erit. J. F'sychiatr. 110,588-593,1964.

Fuchs, C., Dorr, I,., McIntosh, C., Scheler, F. arid Kraft, E.: Comparative calcium ion determinations 
iri flasma arid hole blood with a rew calcium ion arialyaer.

Clir. Chinl. Acta 62: 99-102, 1976.

Garver, Iı.L, and Ilavis, J.M.: MINIfEVIEW: Biogeric amirie hypothesis of affective disorders. Life Sci. 24:383-394,1979.

Gibsor, J.G.: Emotions arid the thyroid sland:

A critical affraisal.

J. Fisychosom. Fies. 6:93-116,1962,

Glowirisky, J. and Iversen, L.L.: Fiegiorial studies of catecholamirıes ir the rat brair.

J. Neurochem. 13:655-669,1966.

Gour, K.N. arid Chaudhry, H.M.: Study of calcium metabolism ir electric corvulsive therafy (E.C.T.) in certain merital diseases. J. Merit. Sci, 103:275-285,1957.

Grima, J. M, arid Erarid, M. J. I.: Activity arid iriterference effects in measuremerit of ionized calcium with ior-selective electrodes. Clin. Chem. 23: 2048-2054, 1977.

Hariseri, S. O. and Theodorseri, L.: The usefulriess of ari imfroved calcium electrode in the measuremerit of iorized calcium in serum. Clin. Chim. Acta 31: 119-122, 1971.

Harris, W.H. and Eeauchemin, J.A.: Cerebrospinal fluid calcium, masnesium arid their ratio in psychoses of orsaric and furictional orisir. 
Yale J. Eiol. Med. 29:117-124,1959.

Iverser, L.L.: Uftake process for biogeric aniries. Ir Haudbook of Esycboebarmacolosy, Iversen, L.L., Iversen, S.Il, arid Sriyder, S.H. (eds.), Fileruun Firess, N.Y., 3:381-442,1975. Jimersor, I.C., Fost, R.M., Carmarı, J.S., varı Kammerı, II.F., Wood, J.H,, Goodwirı, F.K̈, arıd Eurıries, W.E. Jr.: CSF calcium: Clinical correlates in affective illness and schizophrenia. Eiol. Fsychiatr. 14:37-51,1979. Janowsky, I1.5., El-Yousef, M.K., Ilavis, J.M. and Sekerke, H.G.: A choliriersic-adrenersic hyfothesis of maria and defression. Laricet ii:632-635,1972.

Kelly, F.E., Ileutsch, J.W., Carlsori, S.S. arid Wasrier, J.A.: Biochemistry of rieurotrarismitter release. Arırı, Fiev. Neurosci, 2:399-446,1979.

Kiellarid, J.: Irıjividual activity coefficierits of iors in aqueous solutions.

J. Amer, Chem. Soc, 52: 1675-1678, 1937.

Kivirikko, K.I,, Laitinen, 0, and Frockof, [.J.: Modifications of a sfecific assay for hydroxyfroline in urine. Arial. Fiochen. 19:249-255,1967.

Klleir, L.: Steady-state relationsing of calcium-45 between horie and blood: Ilifferences in growing doss, chicks and rats. 
Science 214:190-193,1981.

Ladensor, J. H. and Fowers, Jr., S. N.: Free calcium ir, serum I. Iletermination with the ion-selective electrode arid factors influencins the results. Clir, Chem. 19: 565-574, 1973.

Lew, G,M. and Quas, W.B.: Twerity four hour rhytinmic uftake of $\mathrm{H}^{3}$-riorefiriefhririe iri-vitro by hypothalamis arid medial lower brairistem. Init. J. Chroriobiol. 2:209-213,1974.

Lowry, O.H., Fosebrough, N.J., Farr, A.L. arid Fiaridall, R.J.: Frotein measurement with the folin pheriol reasert, J. Eiol, Chem, 193:265-275,1951. Madser, S. arid 0lgard, K.: Evaluation of a riew automatic calcium iorı arialyzer.

Clin, Chem, 23: 690-694, 1977.

McClure, Il.J.: The role of dofamine in defressior. Carı. Fsschiatr. Assoc. J. 18:309-312,1973.

Melarider, E.T., Ericsor, L.E., Sunidler, F, arid Westgren, U.: Intra-thyroidal amiries in the resulation of thyroid activity.

Rev. Fhysiol. Biochem. Fharmacol. 23:39-71,1975. Melleruf, E.T., Eech, F., Sorenser, T., Fuslsarig-

Frederiksen, A. arid Fiafaelsen, $0 . J .:$

Corresfonderice: Calcium arid electrocorivulsive therapy of defressed fatients. Biol. Fsychiatr, 14:711-714,1979. Mohar, M. S. and Bates, F, G.: Calibration of iori- 
selective electrodes for use in biolosical

- fluids.

C1ir. Chen. 21: 864-872, 1975.

Moore, E. W.: Hydrosen and cation aralysis in biological

fluids in-vitro. In Glass Electrodes for Hudragen and Otber Cations.

G. Eisenman (ed.) Marcel Dekker, Inc., New York.

Cb $15: 412-441,1967$.

Moore, E. W.: Studies with ion-exchange calcium

electrodes in biolosical fluids: Some

afflications in biomedical research and clinical

medicine. In Ion=Selective Electrodes,

R. A. Ilurst (ed,) Nat'1. Bur: Stds,,

Spec. Fubl. 314, Cb Z: 215-285, 1969.

Morsenroth, U.H.,III, Boadle-Biber, M.C, and Roth, R.H.:

Activation of tyrosine hydroxylase from central

noradrenersic neurons by calcium.

Mo1. Fharmaco1 11:427-435,1975.

Naylor, G.J., Fleming, L.W., Stewart, W.K., McNamee,

H.E. and LePoidevin, D.: Flasma masnesium and calcium levels in defressive fsuchosis.

Brit. J. Fsychiatr. 120:683-684, 1972.

Oswald, I., Brezinova, V. and Dunleavy, M.L.F.: On the slowness of action of tricuclic antidepressant druss.

Brit. J. Fsychiatr, 120:673-677,1972.

Pedersen, K. 0 .: Bindins of calcium to serum albumin II. 
Effect of oH via comfetitive hudrogen and cation biriding to the imidazole srours of albumir.

Scarid. J. Cliri. Lab. Irivest. 29: 75-83, 1972.

Federseri, K. 0.: An analysis of measured arid calculated calcium cuaritities ir serum.

Scand. J. Clin. Lab. Irivest. 38: 659-667, 1978.

Fhillis, J.W.: MINIFEUIEW: The role of calcium in the central effects of biogeric aniries.

Life Sci. 14:1189-1201,1974.

Frange, A.J. Jr., Wilsor, I,C., Fabor, A.M, arid Ligtor, M.A.: Eriharicement of imiframirie aritidefressant activity by thyroid hormore. Amer. J. Fsychiatr, 126:457-469,1969.

Fiamar, A.: Iletermination of ionized calcium in serum with a calcium electrode. Biochem. Med. 3:369-375, 1970.

Fobertsor, W. G.: Measurement of ionized calcium in hods fluids - A review.

Arır, Clin. Biochen. 13:540-548, 1976.

Foss, J. W.: Calcium selective electrodes with liaudd ion exchariser.

Science 156: $1378-1380,1967$.

Fioss, S.B. and Ferisi, A.L.: Inhibition of the uftale of tritiated catecholamines by aritidefressarit arid related asents.

Eurof. J. Fharmacol, 2:181-186,1967.

Foss, S.B. arid Feryi, A.L.: Tricyclic antiderressant 
agents. II. Effect of oral administration on the uptake of ${ }^{3} \mathrm{H}$-noradrenaline and 14 C-5-hydrowytryftamirie in slices of the midhrain-hypothalamus region of the rat. Acta Finarmacol et Toxicol. 36:395-408,1975.

Fisbin, F.F.: The role of calcium in the release of rieurotransmitter substances and hormories. Finarmacol. Fiev. 22:389-428,1970.

Salama, A.I., Insalaco,J.Fi, and Maxwell, F.A.: Concerniris the molecular reauirements for the inhibition of the uFtake of racenic $3_{H-r o r e f i n e f h r i n e}$ into rat cerehral cortex slices by tricyclic aritidefressarit comfourids. J. Fharmacol. ExF. Ther, 128:474-481,1971.

Schildk.rast, J.J.: The catecholamire hyfothesis of affective disorders: A review of suffortiris eviderice. Amer. J. Fsychiatr. 112:509-522,1965.

Schildkraut, J.J. and Kety, 5.5.: Eioseric amines arid emotior. Scierice 156:21-30,1967.

Schwarta, H, I, , McCoriville, E, C, arid Christofhersor, E. F.: Serum ionized calcium by sfecific ion electrode. Clin. Chim. Acta 31:97-107, 1971. Schwartz, H. Il,: Serum iorized calcium by electrodes: New techriolosy arid methodology. Clin. Chim. Acta 64: 227-239, 1975. 
Seamorids, E., Towfishi, J. and Arvari, Il. A.:

lletermination of iorized calcium ir, serum by use of an ion-specific electrode.

Cliri. Chem, 18: 155-160, 1972 .

Snyder, S.H. and Cosle, J.T.: Fiegional differences in

${ }^{3} \mathrm{H}$-riorefiriefhrire arid ${ }^{3} \mathrm{H}$-dofamirie uftake irito

brairi homoseriates.

J. Fharmacol. Eær. Ther, 165:78-86,1969.

Squires, F.: Effects of noradrenaline fumf blockers ori its uptake by syriaftosomes from several different brairı resioris: Additional evidence for dofamirie terminals in the frorital cortex.

J. Finarm. Fharmacol. 26:364-366,1974.

Sririvasan, K. ana Fechritz, G. A.: Selectivity studies or liauid membrare iori-selective electrodes.

Arial. Chem. 41: 1203-1208, 1969.

Steel, F.G.Il, arid Torrie, J, H.: Erincieles and Érecedures of Statistics

McGraw-Hi11, N.Y, Cb $9: 161-182,1960$.

Teita, N.W.: Eundaweatals of Clinical Cbemistry,

W.E. Saunders Co., F'nila,. Fa. 919-920,1976.

vari Fraas, H.M.: Central morioamine metabolism in

depressioris: I. Serotorin arid related comfourids.

Coms reher. Fisychiatr. 21:30-43,1980.

van Fraag, H.M.: Central monoamirie metabolism in

defressions. II. Catecholamiries arid related comifourids. 
Compreherı. Fsychiatr. 21:44-54,1980.

Wirier, E.J.: Statistical Ericcieles in

Exerrimental Jesign,

MeGraw-Hill Book. Co,, N.Y., 191-195,1971. 
